\title{
Marginality-A Key Concept to Understanding the Resurgence of Rebetiko in Turkey
}

\section{DANIEL KOGLIN}

In the following pages, I want to compare some of the ways people in Greece and Turkey today understand and use the label "rebetiko," which denotes a type of Greek popular or "urban folk" song recorded mainly during the first half of the twentieth century. While in Greece the music that is now commonly called rebetiko has always delighted numerous fans, it has over the past two decades also gained in popularity on the opposite side of the Aegean Sea. Turkish listeners have, however, not only adopted the Greek notion of rebetiko-i.e., a specific internal representation of the attributes shared by a complex of songs-but they have also adapted it to their own cultural environment. The aim of my essay is to show that an investigation into this matter can contribute to a revision of current views on rebetiko, which thus far has been examined primarily in the light of theories deriving from Greek intellectual debates.

From the study of record labels it can safely be inferred that by the beginning of the twentieth century the term "rebetiko" was already current among the Greek-speaking population of cities within the Ottoman Empire, although it is unclear in which sense it was used. ' Since then, however, Greek journalists, musicians, scholars, record producers, and other authorities have applied the term with some inconsistency to songs that differ considerably in terms of melodic properties, the content and style of their lyrics, or the manner of performance. If one tried to give a one-size-fits-all definition, one would probably not arrive at much more than the vague conclusion that, in an eclectic fashion, rebetiko songs combined elements common to a wide range of musical traditions in the Eastern Mediterranean. This result would, of course, not be a very satisfactory one; and some debaters have actually suggested avoiding the term altogether. ${ }^{2}$ Yet, there is no denying the widespread acceptance of the label "rebetiko." Instead of striving to classify this genre according to formal criteria, I find it more productive to concentrate on its functional aspects-to regard "rebetiko" not as a technical term but as a quite abstract, imprecise or "fuzzy" concept that individuals (whether experts or laypersons) internalize under specific circumstances that each of them uses in a specific context and for a particular purpose. Therefore, any serious examination of this concept requires asking how it "works" within the changing parameters that are set by personal

\footnotetext{
${ }^{1}$ See Kaliviotis, The Music Life of Smyrna, 130.

${ }^{2}$ Rebetiko singer Takis Binis (2004), for instance, complained to his biographer: "The motto of a rebetis is always: 'Since there is death, long live debauchery!' [...] The song, however, must not be called rebetiko. It is not permitted that Greek urban popular song be characterized that way, regardless of the fact that many of us were rebetes and had a corresponding outlook on life" (p. 399, 402). Several students of rebetiko share this view. Nearchos Georgiadis avoids the term rebetiko throughout his book Rebetiko and Politics (Athens 1996) claiming that composers preferred the label laiko tragudhi, i.e. "popular song” (p. 11). In the same vein, Panos Savvopulos (2006) asserts that the label rebetiko "was coined by the record companies in the early twentieth century" and did not gain wider currency until the end of the 1940s (p. 18). And according to Ilias Voliotis-Kapetanakis (2003), Greek urban popular song "erroneously has been termed rebetiko" (p. 33).
} 


\section{Music AND Politics Winter 2008}

dispositions, public discourses, socio-economic conditions, political ideologies, cultural traditions, and so forth.

A clear example of the resultant conceptual fluidity of rebetiko is what one might call its "artistic merit." Rebetiko is often said to initially have been a plebeian music that was created within the underworld of the manges (urban lowlifes), a "shiftless potsmoking lumpenproletariat" comprising large groups of Greek refugees from Asia Minor. ${ }^{3}$ But why is this very music now officially presented as one of the great achievements of Greek civilization? My readers who have watched the opening ceremony of the 2004 Olympic Games in Athens might recall the procession that showcased Greek cultural history from antiquity to the present. Nothing else than a float with rebetiko musicians had been chosen to signal the beginning of the twentieth century. One sees similar developments elsewhere, too, as Peter Manuel's survey of non-Western popular music has fairly shown: "One of the most remarkable features of the evolution of popular musics is its association, in numerous cultures worldwide, with an unassimilated, disenfranchised, impoverished, socially marginalized class. [...] It is paradoxical that these marginal misfits in their milieu of bars and brothels should be so crucial in the development of musical forms, especially since the genres they create are often destined later to become celebrated as national expressions."

This is precisely what happened to rebetiko. What makes its case interesting, however, is that it received a cultural accolade even as it remained, in a sense, a fringe music whose rebellious charm appeals now above all to an intellectual minority. Comparable cases of the educated classes rediscovering formerly despised local musical idioms and idealizing their "marginality" have been observed in other Mediterranean societies as well (Sant Cassia 2000). Yet rebetiko reveals some peculiarities that make it worthy of closer examination, since Turkish intellectuals redefine its marginality in a quite different context. In order to comprehend the resurgence of rebetiko in Turkey in all its specificity, that is, the special needs this type of music satisfies and the reasons that make listening and dancing to it a desirable pastime, we need not only study the historical development of its symbolic functions, but we must also ask what makes its experience so unique.

The present essay can be divided into two parts. In part one I focus on practices whereby listeners in both countries highlight the cultural ambiguity of rebetiko-its being both "ours" and "the others'." In the first section of part one, I glance at recent trends in Greek-Turkish relations as far as they affect the reception of rebetiko in Turkey. This is succeeded by a discussion of the ways Greek and Turkish listeners define "classic" rebetiko. The second section deals with manners of performance and presentation of this music in present-day Istanbul. Part two is dedicated to a diachronic and intercultural comparison of the symbolic and emotional meanings it had and still has for members of intellectual minorities in both neighboring countries. The conclusion briefly surveys two seemingly contradictory though persistent views: first, that rebetiko was a hybrid-and therefore genuine-articulation of modern Greek or Ottoman culture, respectively. My essay can thus be read as a contribution to some of the debates about intercultural mixing in and construction of identities through contemporary popular musics in the Mediterranean, the Balkans, and the

${ }^{3}$ Fatouros, "Night without moon," 27. cf. Petropoulos (2000); Holst (1975); Butterworth and Schneider (1975); Revault d'Allonnes (1973).

${ }^{4}$ Manuel, Popular Musics, 18. 
Near East. ${ }^{5}$ Second, we need to have a fresh look at the theory that rebetiko was an expression of nonconformist individuals who defied established social norms and ruling authorities. After pondering on the implications of these ideas for a moment, I will put up a counter-argument: that the present trans-Aegean fascination for rebetiko rests on its semantic and emotional ambiguity, which encourages listeners to reinterpret it and relate it to their own everyday experiences, rather than on some alleged essence, whether this be subversiveness, hybridity, Greekness, or some other timeless property.

\section{A. The songs of others that are us}

The views Greeks and Turks today hold on rebetiko cannot be fully understood if we ignore the recent history of political relations between both countries, for national clichés have persistently colored the public image of this genre. In the late 1970s, for instance, Greek communist hardliners openly condemned the revival of rebetiko which was then underway in Greece. Much to their indignation, Bülent Ecevit, Turkey's prime minister during the Cyprus conflict in 1974, was quoted in the press as saying that there were "cultural ties" between Turks and Greeks since "they dance and sing the same way." Alarmed by this remark, one leftist writer went as far as to blame the resurgence of rebetiko on those who "seek to detach the Greek people from their national traditions, to distract them from engaging in class struggle and to entangle them with rebetiko, drink and hashish which, in addition, promote the 'Greek-Turkish friendship' that [...] has been carefully planned in the lobbies. ${ }^{\circ}$ In short, he and like-minded commentators interpreted the new popularity of rebetiko as proof that Greece had still not cut itself loose from its oriental past; and worse, that some secret unpatriotic conspiracy was responsible for this. Greeks have always greeted the genre with both suspicion and admiration. In point of fact, this has also been (and, even though the ratio has changed, still is) the case in Turkey. Thus, I shall sketch out the political relations between both countries to show how intimately connected they can be with the musical ones.

The ongoing quarrel between Greece and Turkey has a long history. ${ }^{7}$ Several times during the past fifty years both countries found themselves in conflict and even at the brink of war owing to opposite interests that effectuated interventions into the Cyprus crisis (1955, 1964, 1974, 1983), exploratory oil drillings in the Aegean (1976, 1987), or conflicting territorial claims (1996). Mutual fears and distrust, feeding on each other, have often impeded the improvement of Greek-Turkish relations, as when in 1974 the government in Athens expressed the wish to expand the range of the territorial waters of Greece from six to twelve nautical miles. Without delay the Turkish parliament passed a resolution-which has not been withdrawn since-to regard this as casus belli. Both sides usually interpret such actions of the other as unprovoked hostility and as a sign for expansionist desires because "each side seems convinced that its policies are not threatening the other's

${ }^{5}$ Cf. Özbek (1997); Steingress (2002); Plastino (2003); Aytar and Keskin (2003); Levy (2004).

${ }^{6}$ Arseniu, Decadence in Greek Music, 31; Ecevit quoted in Arseniu, 41.

${ }^{7}$ For detailed accounts and analyses of Greek-Turkish relations in the twentieth century see Çarkoğlu and Rubin (2005), Aydin and Ifantis (2004), Keridis and Triantaphyllou (2002), Yiallourides and Tsakonas (2001), Alexandris et al. (1991) and Constas (1991). 
legitimate interests; that the other party should know this; and, consequently not oppose a presumably harmless policy."

The late 1990s, however, brought a new, moderate, albeit far from settled political climate. The relations between both countries have been ameliorated, especially after the disastrous earthquakes in Athens and Istanbul in 1999, which offered an excellent opportunity for showing neighborliness. İsmail Cem and Georgios Papandreu, then Foreign Ministers of Turkey and Greece, had therefore every reason to celebrate during Cem's visit to Athens in February 2000-and they chose to do so at a legendary rebetadhiko (a bar with live music, predominantly rebetiko). ${ }^{9}$ This climatic change may help explain why over the last years Greek rebetiko songs have been winning an ever-increasing audience in Turkey. Still, it would be wrong to attribute their success to an earthquake which was not a cause but a catalyst with a largely symbolic meaning.

Rebetiko could only have its comeback in Istanbul because appropriate venues and a potentially interested audience already existed. Many establishments that provided entertainment including live music, alcohol, food and dance had traditionally been run by members of the Greek Orthodox community or the Rum, as they are called in Turkey. In these places Istanbullus could hear Greek popular music, including rebetiko songs, performed by local musicians, but also by famous singers from Greece who regularly visited the Bosporus metropolis. ${ }^{10}$ The number of these establishments drastically decreased with the mass emigration of the Rum from Istanbul in the 1950s and 1960s (see TABLE 1). Reminiscent of the events of September 1955, when an angry mob had turned against the Greek Orthodox community, the remaining Rum owners were reluctant to run their bars and restaurants after the 1974 Cyprus conflict for fear of public hostility." Then, however, new Turkish popular music genres began to be performed in these establishments, thereby filling the gap the departure of the Rum musicians had left: Taverna Müziğ $i$, a low-budget branch of arabesk, in the 1970s and a variety of songs by singer-songwriters drawing upon Mediterranean and Turkish traditional styles, often subsumed under the label $\ddot{O}_{z g u ̈ n}$ Müzik, in the 1980s. ${ }^{12}$ In this way, the newly developing genres preserved those spaces where rebetiko was soon to flourish anew-the more so because some $\ddot{O}_{z g u ̈ n}$ artists had prepared the ground for its comeback by drawing public attention to Greek popular music. In the 1980s, it was the politically minded composer Zülfü Livaneli who realized joint performances and recordings with Maria Faranduri and Mikis Theodorakis; and in the following decade, rebetiko itself became the cynosure as the popular group Yeni Türkü released two quite successful albums (1992, 1994) that contained arrangements of rebetiko songs translated into Turkish. Moreover, around 1990 the Turkish authorities lifted their ban on the public screening of Kostas Ferris' film Rembetiko (1983) which, based as it was on the life of rebetiko singer Marika Ninu, the daughter of Armenian refugees from Asia Minor, left a deep impression on many viewers who had little or no acquaintance with the history of the genre.

\footnotetext{
${ }^{8}$ Coufoudakis, “Greco-Turkish relations,” 389.

${ }^{9}$ As reported in the Turkish daily newspaper Milliyet, February 6, 2000.

${ }^{10}$ See Bozi, The Greeks of Constantinople, 335.

${ }^{11}$ Compare the autobiography of the Turkish buzuki player Erol Örter (1998:31-2) who was born in Istanbul in 1938 to a Muslim father and a Rum mother. He performed in his native town during the 1960s and early 1970s. After the Turkish invasion of Cyprus he continued his career in Athens, Haifa and several British cities and returned to Istanbul in 1985.

${ }^{12}$ Cf. Tohumcu, "Representing a Space," 2005.
} 


\begin{tabular}{lcc}
\hline Year & Greek Orthodox & Rate of decrease \\
\hline 1927 & 100,200 & \\
1955 & 80,000 & $-20 \%$ \\
1965 & 48,100 & $-40 \%$ \\
1978 & 7,900 & $-84 \%$ \\
1990 & 3,500 & $-56 \%$ \\
2004 & 1,650 & $-53 \%$ \\
\hline TABLE 1 & Decrease of the Rum \\
population of Istanbul in the twentieth \\
century (source: Alexandris et al. 1991:39, \\
515; Seufert and Kubaseck 2004:162)
\end{tabular}

\begin{tabular}{|c|c|c|c|c|c|}
\hline \multicolumn{2}{|c|}{$\begin{array}{l}\text { Do you think this song is typical of } \\
\text { the genre rebetiko? } \\
(1=\text { very typical, } 7=\text { utterly atypical) }\end{array}$} & \multicolumn{2}{|c|}{ Greeks $(n=36)$} & \multicolumn{2}{|c|}{ Turks $(n=18)$} \\
\hline \multirow{2}{*}{ Smyrnaean } & song $\mathrm{A}$ & 1.8 & \multirow{2}{*}{2.2} & 1.7 & \multirow{2}{*}{1.9} \\
\hline & song B & 2.6 & & 2.0 & \\
\hline \multirow{2}{*}{ Piraean } & song C & 1.5 & \multirow{2}{*}{1.5} & 1.8 & \multirow{2}{*}{2.0} \\
\hline & song D & 1.4 & & 2.2 & \\
\hline
\end{tabular}

TABLE 2 Judgments of rebetiko listeners in Athens and Istanbul indicating that Greeks and Turks have opposite views as to whether the Piraean or the Smyrnaean style represents the classic form of rebetiko.

Interest in the musical tradition of the other side had, during the same period, also intensified among Greeks, mostly of the younger generation. There are two fundamental reasons for this. One is that in the mid-1980s a number of Greek musicians began to rediscover and perform Ottoman secular art music or, as some prefer to call it, "the learned music of Constantinople." Another reason is that in Istanbul, students of Ottoman and Turkish art music can profit from a high educational standard thanks to an unbroken tradition of high-level teaching and performance. Thus, in the course of my fieldwork in Istanbul, in the spring of 2005, I made the acquaintance of four Greeks who had come to Istanbul in order to study Turkish classical and folk music. One of them, a young musician from Kalamata (Peloponnese), was taking ud lessons with a distinguished performer and teacher at the conservatory of the Istanbul Bilgi University. He told me that three years ago he was the only Greek student in this department, whereas today there were about ten. Conversely, the presence of students like him piqued the curiosity of Turkish audiences about Greek music. During the previous year, he and two compatriots would play Greek traditional songs from Asia Minor and the Eastern Aegean several times a week at some music pubs in downtown Istanbul. They offered a musical experience, he claimed, that was both novel and pleasant for many Turkish customers. 


\section{Music AND Politics Winter 2008}

However, I should add a cautionary note here. On a political level it seems still a euphemism to talk about Greek-Turkish friendship. There are now as ever several points of divergence about Greek naval and air sovereignty in the Aegean Sea or about the borders of the Greek continental shelf with its supposed submarine oil deposits. And, apart from political, economic and military interests, it is also national perceptions and common stereotypes that continue to play their part in the persistence of Greek-Turkish disputes. ${ }^{13} \mathrm{I}$ am doubtful whether music is the panacea to remedy this state of affairs, whether we are entitled to hope that "music, purified of political and religious overtones, is perhaps the only vehicle of communication between politically and religiously antagonistic peoples." ${ }^{14}$ Not even musical traditions as profoundly rooted in Aegean culture as rebetiko or Ottoman art music can be regarded as a "bridge" between Greeks and Turks, because members of each people understand and use these traditions in different ways. In contemporary Turkey, for instance, "the evident fact that a significant minority of non-Turks and non-Muslims feel a certain affinity with Turkish/Ottoman art music is apparently a source of legitimation and pride to some [...] while causing embarrassment to others." ${ }^{15}$ Hence we must turn to the imagery individuals in both countries mobilize when they talk about rebetiko.

The idea about prototypal or "classic" rebetiko will exemplify my point. Most commentators distinguish between "old” and “new," i.e., popularized, rebetiko, the borderline falling roughly within the period of the 1941-1944 German occupation when the Greek record production came to a standstill. According to the prevailing view, the classic form of the genre was recorded before the Second World War, whereas the post-war recordings of rebetiko revealed a growing influence of tonal conceptions of Western popular music. ${ }^{16}$

"Old" rebetiko is generally said to comprise two more or less distinct subtypes, the older Smyrnaean style and the subsequent Piraean style. ${ }^{17}$ I will briefly describe the two stylistic stereotypes. The Smyrnaean style was represented by professional singers of both sexes and by instrumentalists who played various tempered and non-tempered instruments such as violin, santur, ud, piano, violoncello, guitar, mandolin or kanun. These musicians were usually immigrants from urban centers in Western Anatolia such as Smyrna (Izmir), Bursa, or Ayvalik, many of whom had undergone formal musical training and could perform Ottoman or European classical music as well as popular songs from diverse ethnic groups within the Ottoman Empire. Songs in the so-called Piraean style, on the other hand, were typically sung by a male singer and accompanied on buzuki, baghlamas (a sort of miniature buzuki), and guitar. As a rule, these instruments were often played by local amateurs, autodidactic musicians from an underprivileged social milieu. Their repertoires, technical abilities, and theoretical knowledge-as regards, for example, musical notation or the Ottoman makam system-were generally much more limited than those of professional performers from Asia Minor.

\footnotetext{
${ }^{13}$ See Evin (2005); Çarkoğlu and Kirişci (2005); Millas (2004).

${ }^{14}$ Monos, "Rebetico," 303.

${ }^{15}$ Feldman, Music of the Ottoman Court, 17.

${ }^{16}$ See Pennanen (1997).

${ }^{17}$ Cf. Petropoulos (2000); Pappas (1999).
} 


\section{Audio Example 1: Ime Prezakias.mp3}

Accessible at: http://dx.doi.org/10.3998/mp.9460447.0002.102

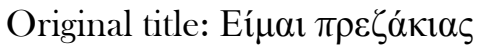

English translation: I'm a Junky

Style: Smyrnaean

Music: Sosos Ioannidis, lyrics: Emilios Savvidis

Interpreter: Roza Eskenazi

Year of first release: 1935

Comment: Parody of a drug-related Smyrna-style rebetiko song written by two theatrical songwriters and sung by one of early rebetiko's greatest female vocalists. Ironically, the versifier Emilios Savvidis later became a member of the censorship board during the dictatorship of Ioannis Metaxas (1936-1940) the role of which was to prevent exactly such "immoral” songs from being recorded.

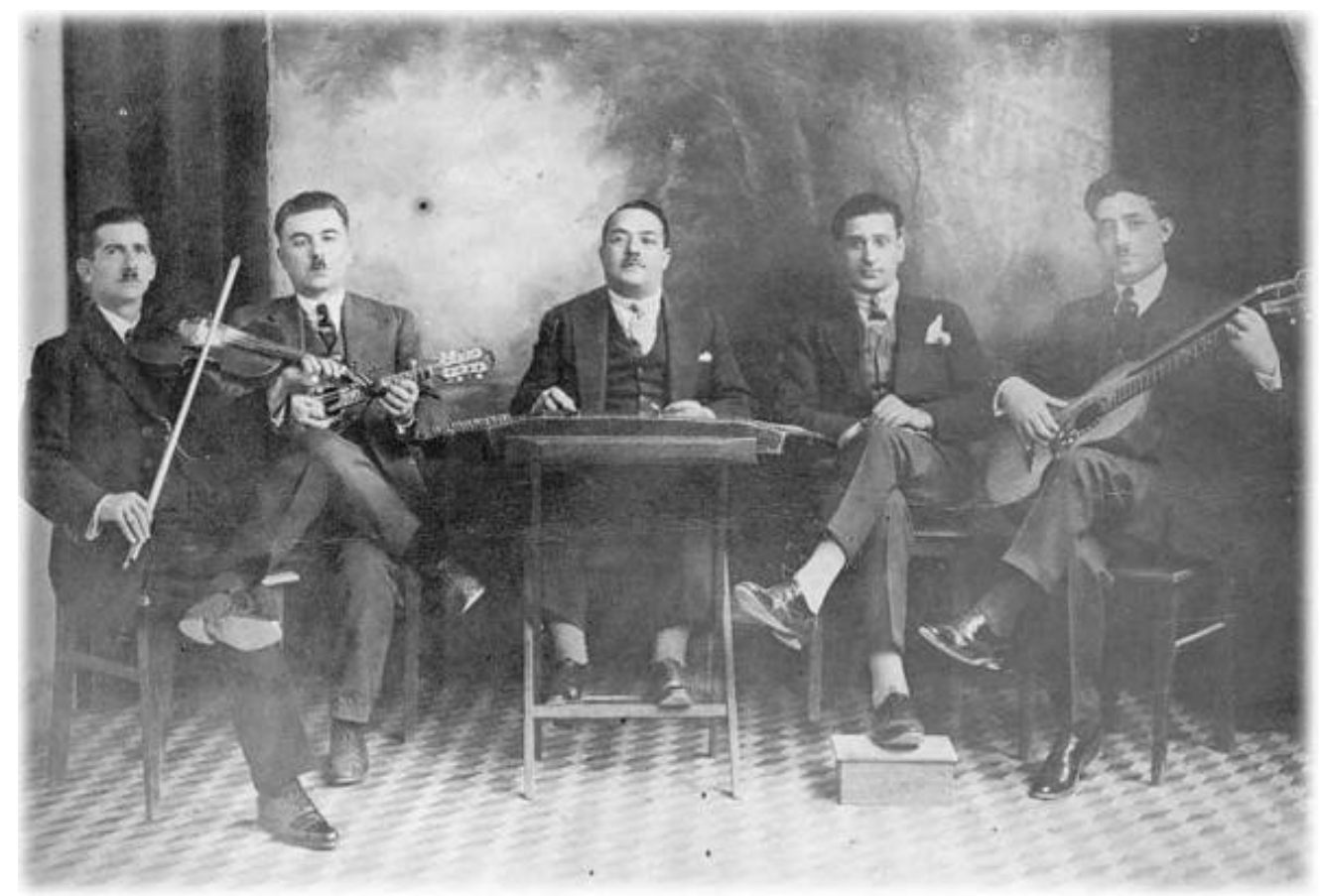

Photograph 1. A typical "Smyrna-style" ensemble consisting of violin, mandolin, santur and guitar. Note how the guitarist's playing position and the footstool of singer Kostas Nuros reflect the influence of Western classical music. The photograph was taken in 1928. 


\section{Audio Example 2: Frangosiriani.mp3}

Accessible at: http://dx.doi.org/10.3998/mp.9460447.0002.102

Original title: $Ф \rho \alpha \gamma \kappa о \sigma \nu \rho \iota v v \dot{~}$

English translation: Catholic Girl from Syros

Style: Piraean

Music \& lyrics: Markos Vamvakaris

Interpreter: Markos Vamvakaris

Year of first release: 1935

Comment: One of Vamvakaris' most famous songs which has reportedly known hundreds (!) of re-recordings-including a reggae version by the Athenian band Locomondo (2005).

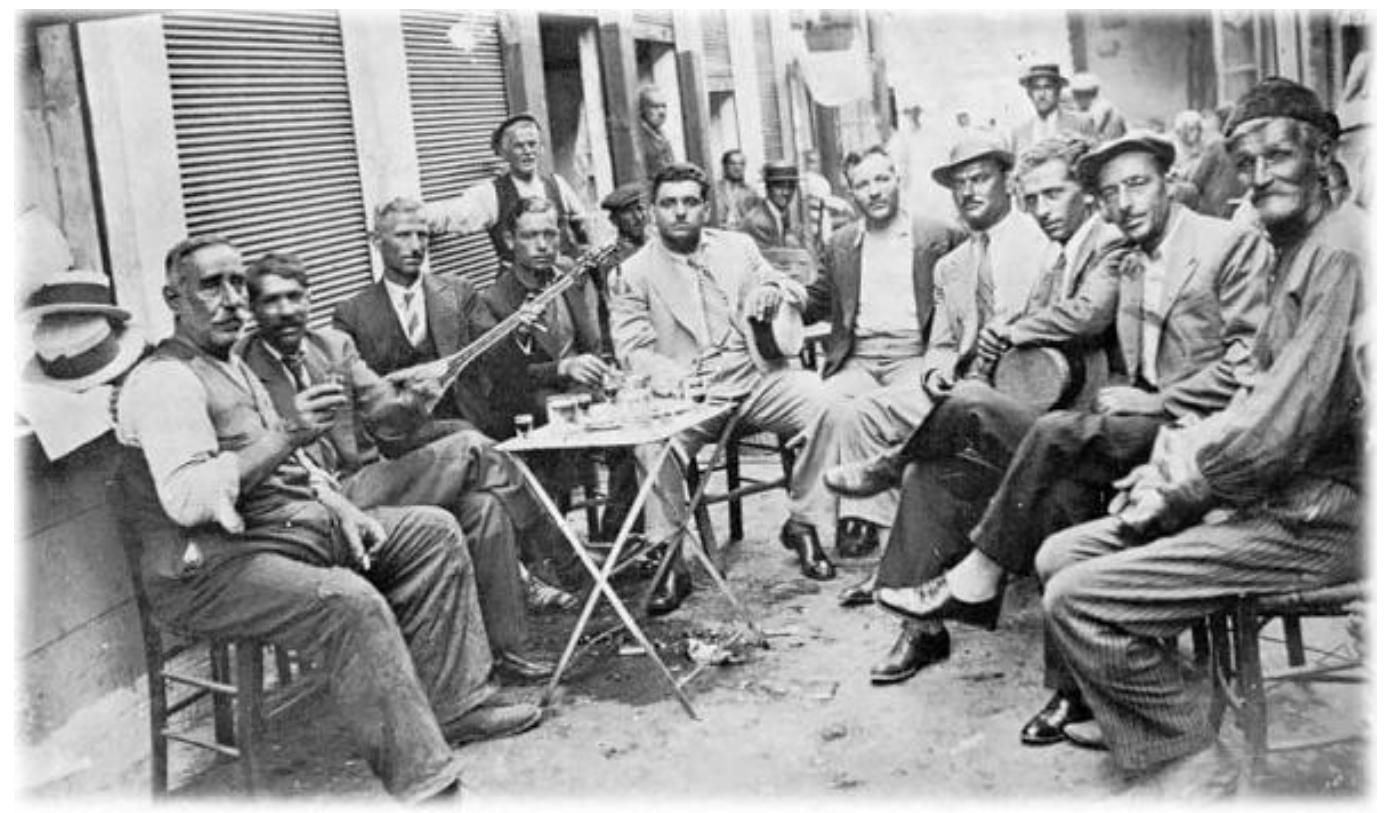

Photograph 2. Piraeus in 1937. Idling men are gathered around the virtuoso multiinstrumentalist Ioannis Eitziridis (third from left), a refugee from Asia Minor who, as legend has it, in his younger days had performed in the harem of Sultan Abdul-Hamid II (1842-1918). 


\section{Audio Example 3: Sinnefiasmeni Kiriaki (orig).mp3}

Accessible at: http://dx.doi.org/10.3998/mp.9460447.0002.102

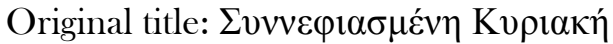

English translation: Cloudy Sunday

Style: "New" or popularized rebetiko

Music: Vasilis Tsitsanis, lyrics: Vasilis Tsitsanis/Alekos Guveris

Interpreters: Prodromos Tsausakis, Sotiria Bellu

Year of first release: 1948

Comment: Something close to a national anthem, this song is one of Tsitsanis' most popular compositions. It represents the "new" style of rebetiko that became popular after the Second World War.

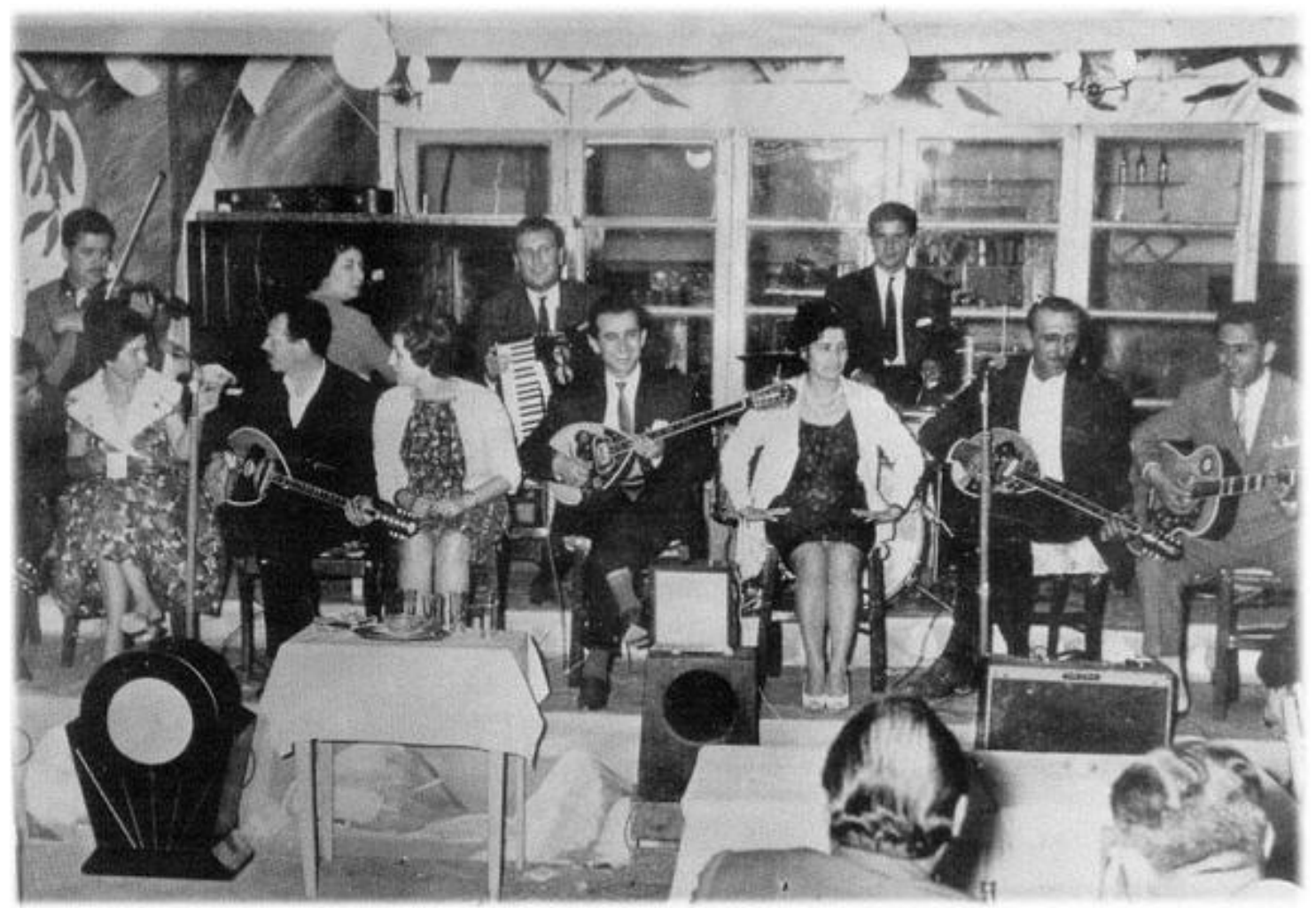

Photograph 3. Athenian nightclub in the early 1960s. Larger orchestras (the one shown includes three female singers and three buzuki players the leftmost of whom is the famous composer Vasilis Tsitsanis) and, eventually, electric amplification helped shape the characteristic sound of "new" rebetiko during the decades following World War II. 
The singer Angela Papazoglu from Smyrna reportedly complained that the local musicians, after she and her colleagues had settled in Piraeus in 1922, "took the songs from us, but because they played them with different instruments the songs sounded differently." ${ }^{18}$ This should awaken us to the possibility of the Smyrna-Piraeus dichotomy signifying differences in instrumentation and playing technique rather than discrete sets of songs. Moreover, the distinction between "Smyrna" and "Piraeus" implies different socio-cultural backgrounds and gender stereotypes of rebetiko performers. Greeks describe musicians from Asia Minor generally as the cultivated representatives of a cosmopolitan Levantine bourgeoisie. The smooth and elaborate singing style of vocalists like Roza Eskenazi, Andonis Dalgas, Rita Abatzi, or Kostas Nuros contrasts markedly with the voice of a Piraeus-type singer like Markos Vamvakaris whose gravelly voice and earthy machismo are felt to indicate a humble social descent and a spiritual affinity to the "underworld."

Today, the labels "Piraeus" and "Smyrna" do not only denote two antipodal Aegean port cities and two more or less distinct ways of performing rebetiko; they also stand for certain cultural ideals which-although projected onto a past reality-in part reflect the present. For listeners of the early twenty-first century, these labels refer to imagined places of origin, not to experienced areas of residence. Their meanings have been stripped of so much of their historical complexity as to become virtually identical with contrasting concepts of national culture (Greek versus Ottoman). It should be no mere coincidence, thus, that 36 Athenians and 18 Istanbullus whom I interviewed between November 2004 and June 2005 had, in at least one crucial respect, significantly divergent notions of what a prototypal rebetiko song is. While listening to two Smyrna-style and two Piraeusstyle recordings, they had to indicate on a rating scale how typical they regarded each song of the genre rebetiko. Responses were graded from 1 (very typical) to 7 (utterly atypical). Since I had chosen only well-known and characteristic songs, the deviations of the judgments were rather small and statistical significance of the difference between the means of Greek and Turkish ratings, as measured by the t-test, could only be proven for the Piraean style. Even so, the emerging tendency is quite clear, as the numbers in TABLE 2 indicate. On the average, Turkish listeners rated the Smyrna-style songs as more typical of rebetiko than the Piraean ones, whereas Greek listeners held the converse to be true.

Suggestive though they are, these numbers are not sufficient to support the claim that Turks consider rebetiko to have sprung from their own musical tradition. Yet how else could one explain that Turkish listeners prefer to illustrate the label "rebetiko" by attaching it to songs performed in the Smyrnaean fashion, i.e., to a genre Pennanen (2004) calls "Ottoman café music?" What else could account for the fact that the titles, illustrations and liner notes of Turkish CDs-but not that of Greek ones-systematically reinforce the association of rebetiko with the Greek Orthodox population of Ottoman cities? ${ }^{19}$ Finally, what else could be the idea underlying the following hypothesis, formulated in a popular Turkish online encyclopedia, that the very term rebetiko was of Ottoman, and not simply of Turkish, origin?

[The names] rebetiko, rebetika, rembetika and rembetiko could have their roots in the term "rebet" which, according to Dr. Abdullah Altıok, probably derives from the word rağbet

\footnotetext{
${ }^{18}$ Papazoglu, Our Fortunes Here, 375.

${ }^{19}$ Cf. Susam-Sarajeva (2006).
} 
[demand]; since in general the songs belonging to this musical genre were popular (much in demand) and could rather easily be learnt and sung by anyone. [...] From this point of view, rembetiko is a word of the Ottoman language. ${ }^{20}$

Thus, a convergence of clues, none of which is individually decisive, can nonetheless lead to the authoritative conclusion that the recent popularity of rebetiko in Turkey is not based on its familiar sound alone. It also rests on the positive value of specific cultural concepts exemplified by rebetiko, particularly that of Ottoman multiculturalism or "tolerance." One of my interlocutors in Istanbul associated rebetiko first and foremost with Istanbul of the Ottoman era. Guitar and kemençe (fiddle) player Cengiz Onural, whom I interviewed in his recording studio in Üsküdar, said he liked rebetiko "because it reminds me of the good old times of Istanbul where Turks and Rum people were living together sharing the values of the brilliant culture of the Ottoman Empire" (March 8, 2005). He was regularly playing rebetiko with Muslim and Rum musicians, composing instrumental pieces for his own ensemble of contemporary Turkish classical music, and also participating in the recording sessions for the album Külhani Şarkılar (1994, Göksoy) by the popular group Yeni Türkü that contained some of his translations of rebetiko songs into Turkish. To him, rebetiko symbolized a bygone humane, cosmopolitan mentality. It referred to an Istanbul before 1922 where, to recall the novelist Ahmet Hamdi Tanpınar (1901-1962), "rich and poor, all classes, would entertain together."

This definitely does not mean that in pre-World War I Istanbul social, religious and ethnic distinctions were insignificant. "What today is often retrospectively-and in a rather sentimental and nostalgic way-perceived as pluralism or even cosmopolitanism was in fact a diversity which could not possibly develop into any real integrative process before the appearance of a supra-communal or supra-religious ideology that would have offered a more sophisticated and abstract locus of allegiance, thus potentially overriding any other form of identity/solidarity." ${ }^{22}$ However, few would disagree that in present-day Istanbul the idea of a cosmopolitan Ottoman past stands in marked contrast to the experience of a social reality that has been shaped, to a large extent, according to the demands of Kemalist nationalism, the official ideology of the Turkish Republic at least until the 1980s. The present interest in rebetiko needs therefore to be seen in connection with a current “vogue for nostalgia” which, as Martin Stokes (1996) proposed, is related to

.... a sense of failure (experienced in a variety of contexts) of the nationalist reform project [...] a quiet recognition that an ideology which demanded that the [Ottoman] past should be forgotten was untenable. [...] Many Turks today portray the Ottoman past as a moment of imperial glory when Turks dominated the world stage; a world in which the various millet (religious minorities) of the Ottoman empire participated as equals in an East Mediterranean linguistic, literary, architectural, dietary, and, of course, musical culture.

In other words, rebetiko represents a minority culture that is now often deemed to have stimulated the development of the dominant main culture, i.e., that of the Muslim Ottomans (which is, incidentally, just what most Greeks today say about the contribution of the Asia Minor refugees

\footnotetext{
${ }^{20}$ Emphases in the original. (Accessed 25 May 2007) <http://tr.wikipedia.org/wiki/Rebetika〉

${ }^{21}$ Quoted in Duben and Behar, Istanbul households, 29.

${ }^{22}$ Eldem, "Istanbul," 154.
} 
to Greek culture after 1922). Though being the music of the others, of a non-Muslim ethnic minority, rebetiko is therefore perceived in part as ours by Turkish listeners. Discovering rebetiko means "rediscovering my own past," as a Boğaziçi University graduate in sociology put it, whose grandfather had lived in Thessalonica and could speak Greek and Ladino, the language of that city's formerly large Jewish community. In his eyes, rebetiko "has Turkish roots. [...] There's a bond between me and this music, because it makes use of cultural elements that I also use. But you know what the problem is? This is the lost history of Turkey. This [i.e., the Rum culture] is something we lost. So it's nice to trace back this history. That's why I learned Greek, because I thought it was a part of my history." ${ }^{23}$

Many commentators representing the Greek urban middle class have, on the other hand, tended to define "authentic" rebetiko as an expression of social marginality: as the songs of lowlifes (criminals, drug addicts, pimps, black marketeers) commonly referred to as rebetes. ${ }^{24}$ The following, slightly unsympathetic and clichéd description of Istanbul's pre-war rebetiko culture-located in Fanari (Fener), then a predominantly Rum district-represents a view that must have been widespread among the Greek-speaking bourgeoisie of the time, in Istanbul as much as in other cities around the Aegean. It is quoted from the memoirs of Haris Spatharis (1988) who was born in Istanbul in 1906 and emigrated to Greece at the age of sixteen:

There were some taverns frequented by rebetes who brought the quarter into such disrepute that we kids were forbidden to go there [...] and we saw the situation there and were afraid to get near the rebetiko taverns. [...] One day I slipped away to this disreputable quarter and, filled with apprehension, met the rebetes. I saw an organ-grinder [...] and his suite of whining rebetes who all of a sudden hollered verses of their songs: "Whenever you come near I praise my luck / And when you go away I weep and sigh / [...] I love the widows that are dressed in black / And break the heart of ev'ry lad apart." The rebetes followed blind drunk, half-erect, with their arms around each other, cigarettes between their lips and their sashes trailing behind them etc. Some kids, apparently trainees being taught how to keep alive and perpetuate the rebetiko tradition, [followed] in their wake; they did certainly not imagine that this task was of such "importance" for the Greek nation that [one day] personalities of contemporary Athens would take care of it. [...] It struck me as rather strange that some police constables who passed the drunk, ignored them completely. [...] I came back home upset by my discovery and did, of course, not tell anybody of my illicit walk in exotic places. Let me point out that in those days and much later the characterization "rebetis" was an insult for most people who were incredibly undemonstrative and tidy. ${ }^{2.5}$

To sum up, audiences in both Turkey and Greece define rebetiko as the musical tradition of a minority, either ethnic or social, within their own society. Accordingly, they label those songs as classic that they perceive to represent the vernacular musical idiom. Had I to condense it into one sentence, I would say that in both cases, rebetiko is considered as the music of socially, ethnically and historically distant "others" that, strangely enough, belong to "us" nevertheless. This ambiguity

\footnotetext{
${ }^{23}$ Interview, March 8, 2005.

${ }^{24}$ See Gauntlett (1991) and Vlisidis, Aspects of Rebetiko, 165-212, for reviews of the Greek debate on the connection of rebetiko with the underworld.

${ }^{25}$ Spatharis, Things Constantinopolean, 435-37.
} 
is, as will be argued in the next section, an important aspect of the presentation of rebetiko in Turkey.

In a sense the rebetes' position is comparable to the one the Gypsies occupy in many societies round the Balkan peninsula and the Mediterranean. From the point of view of the "ordinary" members of these societies, both appear as music-making "others" in their midst who inspire them with both admiration and distaste for their special abilities and way of life. ${ }^{26}$ One of my consultants in Athens, a 37-year old buzuki player, even claimed there was "a Gypsy element” in rebetiko "inasmuch as we dance, drink, revel." ${ }^{27}$ Still, I would caution against treating the words "Gypsy" and "rebetis" as equivalents since they are used in quite different ways. Usually somebody is labeled a rebetis (or a rebetissa) to indicate that he (she) lives a specific lifestyle-which may, or may not, include composing or performing "rebetiko" songs-and perhaps holds certain characteristic convictions. It would be nonsense, however, to say that people had been "born" rebetes, that they belonged to a "clan" of rebetes or spoke "Rebetish" as their mother tongue. Such statements are meaningful only if they are made about Gypsies. Besides, there are a number of rebetiko songs that use a widespread romantic image of the Roma and associate Gypsy women with exotic beauty, passion, irrationality, and fortune-telling. At least in this respect, the views of rebetiko songwriters harmonized much better with that of "ordinary" people than the phrase "music-making others" suggests.

\section{B. Rebetiko in Istanbul-a reassimilated exoticism}

If we take seriously the claim that "rebetiko" is a concept, the meaning of which is highly dependent upon varying contextual parameters, then it is necessary to say a few words about contemporary performances of songs that are associated with this concept. Since an extensive discussion of the so-called "rebetiko revival" in Greece is already available in the English language, I can allow myself to concentrate on the yet unexplored microcosm of rebetiko in Istanbul. ${ }^{28}$ My main concern here is to compare the approaches of certain well-known rebetiko musicians in Istanbul. Their juxtaposition can flesh out our understanding of the aforesaid ambiguity of rebetiko in instructive ways, for in each case another aspect of its belonging to "us," and to the "others," is thrown into relief.

Today, the Bosporus metropolis has a population of an estimated twelve million, which outnumbers the Athenian citizenry by about three to one. Though Istanbul has always been in a state of cultural diversity, things have become truly intricate since the city's opening up to the world economy and globalized consumption in the $1980 \mathrm{~s}^{29}$ As a result, a lively mosaic of multifarious musical networks and internationalized record labels has come into being-and rebetiko undoubtedly has become a part thereof. Now that the local rebetiko tradition of the Rum

\footnotetext{
${ }^{26}$ See e.g. Van de Port (1999), Pettan (2001) for a discussion of the relations between Gypsy musicians and their nonGypsy audiences in various parts of former Yugoslavia.

${ }^{27}$ Interview, December 8, 2004.

${ }^{28}$ See Tragaki (2007)

${ }^{29}$ See Keyder (1999).
} 
population has long since been interrupted, the presence of rebetiko depends to a significant extent on the influx of compact discs from abroad. During a single evening walk down İstiklal Avenue, a long pedestrian way in the Beyoğlu district, I counted two rebetiko recordings and one modern Greek pop song blasting out from the speakers of three different record stores. Some of the storekeepers may be rebetiko fans, but a more plausible explanation is that this music just sells well.

My Istanbul consultants, Muslim as well as Rum citizens, had become acquainted with rebetiko in a variety of ways. Among them were professional and amateur musicians, ordinary listeners with a predilection for Greek music, students of Greek dances, researchers who studied the music of various ethnic groups in Anatolia, assistants in record shops, and personnel of a bar with Greek live music. But while Greek rebetiko aficionados often amass digitalized editions of prewar recordings and, if truth be told, have to grapple with the problem of oversupply, my informants in Istanbul knew many songs only through reinterpretations by contemporary, internationally famous Greek artists like Yorgos Dalaras, Haris Alexiu or Glykeria. They had much fewer opportunities than Greek consumers to purchase so-called “original” recordings of rebetiko.

Three major exponents of rebetiko music in Istanbul will now be portrayed in some detail as they personify distinctive outlooks on the Greek musical tradition. The work of buzuki player Orhan Osman, who was brought up in the Turkish-speaking Muslim community of Komotini (northern Greece), can be labeled "synthetic" inasmuch as it blends musical sounds from different geographic and cultural surroundings. His music is a complex amalgamation of local and global styles that mirror personal experiences as well as current trends in Istanbul's music industry. ${ }^{30}$ After moving to Istanbul in the mid-1990s Osman continued to perform Greek popular music the way he had done in his native town and in Athens, but he did not win much applause. During our first meeting, in late March 2005 at a restaurant on Taksim Square (Beyoğlu), he told me that in both Greece and Turkey it had annoyed some people that a Muslim was playing Greek music. Since then, though, things had changed. Over the years he had developed "a style of my own," claimed Osman who had barely entered his thirties, by mixing jazz with music from the Balkans, the Near East and India-although he emphasized his being rooted in Greek popular music. In this way he made a name for himself throughout the country, even in some remote eastern regions where nobody had heard a buzuki before. He also pointed out that he was now the leader of a fortymember orchestra (with whom he was just about to go on tour to England) including a whirling dervish, a flamenco dancer, an Indian vocalist, and a Greek rebetiko ensemble. And he hosted a TV show on a public broadcasting network channel, TRT, where each Friday night he presented musicians from different parts of the world and jammed together with them.

Compared with the world music style of Orhan Osman, accordionist Muammer Ketencoğlu's approach was much more purist; and pre-war recordings of rebetiko songs, of which he possessed an extensive collection, remained his point of reference. ${ }^{31}$ In one of our conversations, at a small tea

\footnotetext{
${ }^{30}$ See Stokes (1999).

${ }^{31}$ On November 3, 2006, Muammer Ketencoğlu and his co-musicians-two Rum singers and four Muslim instrumentalists (guitar, violin, ud, percussions)_gave a concert entitled Ege'nin iki yüzü (“The Two Faces of the Aegean”) in Istanbul's reputable Cemal Reşit Rey Concert Hall. The event was announced as a performance of "Turkish and Ottoman-Greek [Rumca] folk dances and songs from Asia Minor as well as Izmir-style rebetiko.” Both the venue and the presentation of this event are emblematic of the way the ambiguity of rebetiko is marketed in Turkey today.
} 
room near his home in Beyoğlu, he said he was among the few performers of rebetiko in Turkey who had done "serious" research and knew what they were talking about (March 9, 2005). Born in a town about sixty miles southeast of Smyrna, Ketencoğlu had been initiated into Greek popular music at a young age by a Muslim immigrant from Greece. In this way he had discovered that rebetiko was "the genre that I can most easily understand and identify myself with" as its themes were "very close to those of Anatolian music." This early attachment to musical traditions round the Aegean still seemed a decisive factor in Ketencoğlu's musical choices. Apart from rebetiko, he presented folk music from the Balkans and Asia Minor in his concerts, on his albums, and during his weekly music program on a non-commercial leftist radio channel in Istanbul.

In Greece both these principles, the synthetic and the traditionalist, are put into practice as well. As to the former approach, it is mainly Piraeus-style rebetiko that has been mixed with globalized musical idioms. Blues has been tried by several artists; Greek hip hoppers have sampled from old rebetiko records. Recently, an Athenian band released a reggae version of Markos Vamvakaris' famous song Frangosiriani. ${ }^{32}$ But the Piraeus model still inspires original compositions in a conventional style as well. During an open-air rebetiko concert in Athens in June 2005 the prominent singer-songwriter Aryiris Bakirtzis presented a song à la Vamvakaris to an enthusiastic audience, which he had written several years ago on the occasion of the shooting down of a U.S. Stealth Fighter during the war in Serbia. These are, however, exceptions to the rule of strictly conservative performances of classic songs, both by rebetiko authorities of today and by myriads of anonymous professional and amateur ensembles.

Contrariwise, a third approach, which might be dubbed the "Orientalist" one, was something I only found in Istanbul-in a luxurious hotel near the Palace of the Sultans, to be precise.

The night I went there, Greek buzuki player Yannis Saulis, his Turkish wife Görkem and their ensemble performed on a small, wooden stage at the hotel's restaurant. Waiters in livery walked swiftly to and fro serving select dishes of Mediterranean cuisine. The diners conversed in a lively manner throughout the evening both in Greek and Turkish, but as the orchestra had electric amplification this did not bother the more attentive listeners. The event was spiced with a good dose of retrospective Orientalism. While the band was playing, black-and-white photographs of old Istanbul and of whirling Mevlevi dervishes (highly educated members of a distinguished Sufi lodge and dignitaries of Ottoman civilization) were projected onto a screen next to the stage. Saulis' Turkish fellow musicians performed on their instruments (violin, kanun, guitar, ud and darbuka) in the characteristic virtuoso style that betrays the graduate of the State conservatory. Nobody in the audience sang or danced-except for a lonely couple who once performed a slow waltz.

Despite the fact that the audience, myself included, enjoyed the evening, this was a far cry from the informal atmosphere and tumultuous joie de vivre one often experiences in Greek rebetadhika.

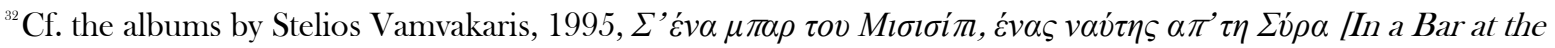
Mississippi, a Sailor from Syros], PolyGram; George Pilali (1994) $\Theta \varepsilon o \kappa \omega \mu \omega \delta i \alpha$ [Divine Comedy], Aristokrates (1994);

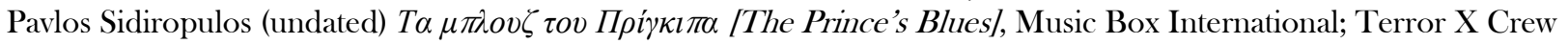

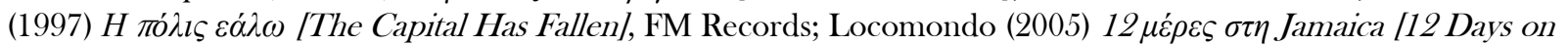
Jamaical, Music Box International.

${ }^{33}$ Fieldnotes, March 23, 2005.
} 
There were, however, a number of places in the district of Pera (Beyoğlu) where rebetiko songs could be heard in a much more casual ambience-and this is the fourth way of performing rebetiko I want to discuss here. In its heyday during the nineteenth century Pera had been inhabited by European merchants, military attachés and embassy officials with their families. But there was also a darker side to life in this quarter. "Although Pera came to be considered desirable because of its European character, its reputation among Europeans was somewhat tarnished. Early in the [nineteenth] century it attracted adventurers and even criminals from Mediterranean shores." ${ }^{{ }^{4} 4}$ It was, moreover, famous for its wine bars, many of which were run by local Rum, Armenian, and Jewish citizens whose faith did not interfere with their profession. Most of the non-Muslim inhabitants of Pera left the country in the course of the twentieth century (see above); and in the 1950 s the families of poor rural immigrants began to inhabit their dilapidated houses. Yet remnants and recreations of a "cosmopolitan" past can still be seen today. Of all the parts of Istanbul, Beyoğlu has probably the highest density of bars, cinemas, shopping streets, European embassies, brothels, nightclubs, and Christian churches, partly as a result and partly in spite of large-scale urban renewal projects in the 1980 s which aimed at rehabilitating and modernizing the area. ${ }^{35}$

Looked at from this angle, the matter presents a historical dimension whose significance we must recognize. Much of Istanbul's rebetiko soundscape spreads over a quarter, by tradition linked with music, drink and entertainment. To give an idea thereof I will recount some personal impressions from a night at a wine bar (meyhane) operated by a Rum family near the Galatasaray Lyceum, in the heart of Beyoğlu:

"Let us wine, dine and entertain you in an old Rum house...," ran the headline of a flyer I picked up at the entrance of the small meyhane. Situated on the first floor of an old-world Europeanstyle building, its interior walls were painted blue and white-the national colors of Greece-and decorated with a fishing net and posters showing postcard motives from Aegean islands. All the tables were occupied by a mixed public of various ages. The company I was in comprised of both Muslim and Rum Istanbullus some of whom were regular customers. Two of their number were taking lessons in Greek popular dances given weekly by a Rum teacher named Angelos in an apartment above the meyhane. A lonely musician, a tall, thin Turk in his fifties, sat in a corner plucking at the strings of his buzuki, while a synthesizer provided playback accompaniment. He also did the singing, yet fairly often he handed the microphone over to a stout, elderly, jovial Rum vocalist. There was much dancing, clapping and cheering as they took turns in rendering both Greek and Turkish songs. The Greek repertoire, which was dominating, included "old” and "new" rebetiko, but also recent pop hits and some songs in a style reminiscent of mid-twentieth century Western European light music. On one occasion, a young couple got up from their table at the other side of the room and began to dance a chasapiko (a popular Greek dance in duple time where two or three dancers hold onto each others' shoulders and must synchronize a pretty intricate series of steps). Their choreography differed noticeably from the one Angelos had taught my companions. When remarking on this, I was told that several dancing schools around

\footnotetext{
${ }^{34}$ Karpat, "The Population," 98.

${ }^{35}$ Cf. Bartu (1999).
} 
Taksim Square, the main square in Beyoğlu, had begun to offer special courses for those eager to learn Greek dances. Obviously, that couple were practicing what they had learnt elsewhere. ${ }^{36}$

In my experience, it would be improper to present rebetiko that way in a Greek rebetadhiko where, for instance, the absence of electronic instruments is considered a prerequisite for an adequate performance, and Western-style or modern Greek pop songs are taboo. Yet Turkish meyhane customers should be perfectly familiar with this form of presentation: stylistic mixture was a characteristic feature of the Taverna Müzĭgi performed in many of these establishments in the 1970s and 1980s, often by a male singer who sang on his own while accompanying himself on a keyboard. At the same time, it is no longer any old meyhane but an "old Rum house," decked out in a rather touristy Mediterranean style, where people go to hear some Greek buzuki. Rebetiko has now become something out of the ordinary, a slightly "exotic" music that refers to remote points in space and time.

As the increased demand for Greek dancing classes indicates, this particular way of performing rebetiko is no isolated incident, but part of a broader trend. I quote from a recent account by an Istanbul-born Greek publisher who visited his birthplace on the occasion of an international book fair: "On a Saturday night, at a meyhane in close proximity to the Galatasaray stadium, a band played beautiful Turkish pieces, using kanun, ud, violin and def, and then the top name of the spot, a young Turk with a buzuki, known by his pseudonym Alekos, sang [songs by the "rebetiko" composers] Tsitsanis, Kaldaras, Chiotis and Bithikotsis. The whole place was up and dancing zeibekiko and chasaposerviko." ${ }^{\prime 7}$ In a meyhane setting, the program, the orchestration, the reactions of the audience (terpsichorean activity is, it seems to me, much more intense there than in the average rebetadhiko in Greece) and a host of other factors give rebetiko a distinctively "Turkish" flavor; yet its "Greekness," i.e. its being different, is intentionally underlined through interior decoration or Greek pseudonyms as well. In spite of its reassimilation, rebetiko remains an exoticism-and this does not only happen at the meyhane. To summarize the foregoing discussion, a tabulation of its main points is helpful. TABLE 3 shows some of the ways and senses in which each of the four performance types (synthetic, traditionalist, Orientalist, and meyhane) serves to present rebetiko in an "exotic" light. The right column lists on the other hand, specific traditions of "Turkish" music which rebetiko is related to.

\footnotetext{
${ }^{36}$ Fieldnotes, March 17, 2005. Not unlike a Greek rebetadhiko, a meyhane is a place where friends spend a night on weekends to hear live music (usually Turkish popular genres), chatter, laugh, consume meze snacks and large amounts of rakı-a strong alcoholic drink that has the flavour of aniseed-and sooner or later break into dance and cheerful group-singing.

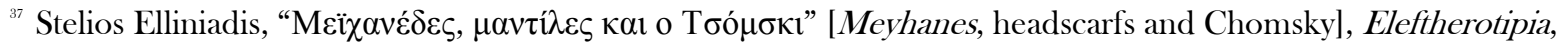
January 18, 2004.
} 


\begin{tabular}{lll}
\hline & \multicolumn{2}{c}{ Turkish musicians and their audiences relate rebetiko to: } \\
Approach & "other” times, places, cultures & "our" musical tradition \\
\hline 1. synthetic & - Greece ("ethnic" sound) & - Turkish World Music \\
2. traditionalist & - yesteryear (old recordings) & - Anatolian folk song \\
3. Orientalist & - Ottoman era (slide show) & - Turkish classical music \\
4. meyhane & - non-Muslims (alcohol) & - Taverna Müziği \\
& - Greece (décor, dances, & - songs of the Rum citizens of \\
& buzuki, pseudonyms) & Istanbul
\end{tabular}

TABLE 3 Four approaches to performing rebetiko that musicians in Istanbul have adopted. In each case, rebetiko is identified with some specific part of the musical tradition of Turkey (right column). At the same time, various aspects underline its being closely linked to temporal, geographical or cultural concepts that imply otherness and distance (middle column).

To perceive one and the same music as both familiar and exotic, as "ours" and "theirs:" here is what is crucial in the resurgence of rebetiko in Istanbul. In some contexts, rebetiko is pushed as far afield in the listeners' conceptual space as Greece or the Ottoman era. Then again, rebetiko close up as a specific performance emphasizes its relatedness to contemporary local musical traditions. This illustrates a central idea of the present article which will be further explored in the second part: if the semantic oscillation of rebetiko between different categories, while not simply an inevitable result of musical cross-breeding or modernization processes, is understood to be attributable to its incomplete adaptation and redefinition by new "users," then the focus of inquiry shifts from "How could we, as scholars, dissolve the ambiguity of rebetiko?" to a more constructive "Why and to what end do the people we study not dissolve it?"

\section{The elevation of a baseborn genre}

I asked my informants in Athens and Istanbul how they felt and what they thought of when listening to rebetiko songs. Their answers harmonized remarkably well with each other. First, most individuals in both cities associated rebetiko with intense "excitement" or "passions" of the "soul." They described the songs as "effusive," communicating feelings that could, at the same time, be both negative (such as "sadness," "bitterness" or "sorrow") and positive (like "happiness," "enthusiasm," "love” or "joy"). Some Greek consultants used the oxymoron charmolipi-which can be translated as "sweet sorrow"-to describe this peculiar in-between state of the soul and emphasized it was one of the most characteristic emotional qualities of rebetiko. Second, listeners in both cities interpreted rebetiko lyrics as verbalizations of the feelings and experiences of "poor people" living on the "margins" of society. The song texts, some added, revealed a spirit of "resistance" against conventional middle-class beliefs and social norms, praising certain forms of behavior which could involve the "infringement" of official laws.

In view of the standard literature on rebetiko, the opinions of both groups seem too unanimous and self-evident to require further explanation. If we go into detail, however, the 
apparent congruence turns out to be delusive: for even if the words Greeks and Turks applied are the same, their meanings are not. Take the phrase "Rebetiko songs express the tragic fate of social outsiders" as an instance. Both parties may perfectly agree it was an apt description of this genre; and they may even specify what is meant by "tragic fate" in the same way (expulsion, poverty, alienation). But what matters is the disparity in their viewpoints. My Greek informants associated rebetiko with "refugees from Asia Minor" and with Greek port cities, especially Piraeus, where many of the refugees had settled after their arrival. In the minds of Istanbullus, however, rebetiko conjured up visions of the "Aegean Sea" and her maritime provinces in Anatolia, which is where the Rum population of the Ottoman Empire used to concentrate. ${ }^{38}$ Small as it may seem, this difference is by no means of little importance. For Greeks the term "Smyrna" symbolizes Ionia, the oriental wellspring of Hellenism. Orestis Lindermayer (1999) has cogently argued that "Smyrna" stands, in the eyes of most Greeks today, for a grand and ancient urban culture-anything but a "backward" Orient, that is. This culture is often considered to have been ethnically purer than and superior to that of the population of the Greek mainland which had intermingled with other Balkan ethnicities and was felt to be comparatively boorish in its habits. Turks, on the other hand, tend to associate "the Aegean" with European culture. "Turkey is well aware of the fact," a Western expert suggested, "that Greece, unlike herself, is regarded as a 'natural' part of the West and of Europe." Consequently, the repeated efforts of Turkish governments "to get a certain share of the Aegean and to prevent the Aegean from becoming a 'Greek sea'" may at least partly be based on the assumption that "any country that can claim to be an Aegean country is a European country as well. ${ }^{39}$ This observer enters dangerous ground as he subsumes a multitude of views and interests under the name of a single nation. However, if his general hunch is right, then it might not be too hyperbolical to say it is in a cultural sense-not only in a geographical one-that Smyrna represents the (Hellenic) "East" for Greeks but the (European) "West" for Turks.

Moreover, this semantic difference would provide an explanation for the fact that Turkish rebetiko fans, unlike their Greek counterparts, pay a good deal of attention to the allegedly "cosmopolitan" aspects of rebetiko. They eulogize it as a music which, as part of the bygone Ottoman culture, had added a unique color to the flower garden of human civilization. "I love rebetiko songs," an amateur musician and English teacher at Istanbul's Boğaziçi Univerisity wrote to me, "because they remind me of a bitter history across the Aegean-starting on the Eastern shores, ending in the West. And I regret being a member of the suppressing and ruling majority on this side. A great culture has been swept off the surface of Anatolia and I believe it's a great loss for the whole mankind. And the songs perfectly reflect the bitterness of this tragic phenomenon, even when they seem to be more joyful." ${ }^{\text {to }}$ What one has to keep in mind when reading these lines is the common and implicit assumption that until the advent of nationalism-which my consultant held responsible for that bitter history, presumably-the Rum of Smyrna and their music could flourish under the permissive rule of the Sublime Porte, in a city that by the end of the nineteenth century

\footnotetext{
${ }^{38} \mathrm{Cf}$. the above description of the Rum meyhane.

${ }^{39}$ Kramer, "Turkey's relations with Greece," 65-66.

${ }^{40}$ Emphasis added. Email correspondence, April 10, 2005.
} 
had become "one of the most eminent cultural and commercial centers in the world." ${ }^{41}$ In the last analysis, then, the difference between the Greek and the Turkish understandings of the term "Smyrna" (and, by implication, "rebetiko") translates into the following dichotomy: while Greeks equate Smyrna with Hellenism in its most "pristine" form, Turks view it as a perfect example of Ottoman "cultural pluralism.”

To put it another way, the great culture whose death mankind had to deplore was, according to the line of reasoning exemplified in the above email, not only that of the Anatolian Greeks but the whole of Ottoman civilization. Together with an ethnic minority vanished what is today seen as an "Empire of Tolerance," to quote from the cover of the compact disc Rembetiko from Istanbul (2001, İmaj) by ney player Kudsi Erguner and his ensemble including kanun, tanbur, ud, violin, clarinet, buzuki, and def. Owing its existence not only to the current promotion of multiculturalism in Turkey but also to a revival of Ottoman art music which set in during the late 1980s, this album demonstrates convincingly how much the ideological realities that inform the ways Turks perceive rebetiko, differ from those in Greece. ${ }^{42}$ As the ney is an emblem of the religious branch of Ottoman art music, it is definitely not a meaningless gesture to perform drinking songs of the Rum inhabitants of old Istanbul on this spiritual as well as Ottoman instrument par excellence.

While in Turkey rebetiko is thus backed by intellectuals with a "pro-Ottoman" cosmopolitan outlook incompatible with the nationalist, Western-oriented mindset of the staunch Kemalists, Greek leftist scholars and their numerous readers tend to view the pot-smoking protagonists of Piraeus-style rebetiko as successors of the heroic klephts of the Greek War of Independence. ${ }^{43}$ Accordingly, they define rebetiko as the songs of eccentric, nonconformist individuals who opt out of a bourgeois society that slavishly imitates Western models. Hence in both cases admiration for rebetiko indicates that parts of the intellectual elite view indigenous culture, however idealized, as an alternative model to the Western one. Yet, it would be tantamount to self-delusion to ignore the substantial differences between Greece and Turkey regarding history, cultural values, or political structure-a point to which I must soon return.

In Greece, a rapprochement of rebetiko and "serious" music analogous to the one realized on Erguner's album Rembetiko from Istanbul, had begun several decades earlier. Representatives of Greek art music, however, did not use the forms and instruments of Ottoman but of European classical music; and they chose motives or even entire melodies of "new" westernized rebetiko as raw material. A movement of Nikos Skalkottas' unfinished Concerto for Two Violins (1944/45) consists of dodecaphonic variations on the theme of a well-known song by Vasilis Tsitsanis. Manos Hadjidakis used songs of the latter in his music for ballet, Six Popular Paintings (1950), after having said publicly that Tsitsanis' melodic imagination, which produced lines "of an amazing content and simplicity, is akin to [that of J. S.] Bach." Mikis Theodorakis followed this track with a recording of the song-cycle Epitaph (1960), interpreted by rebetiko singer Grigoris Bithikotsis, and with his "folk

\footnotetext{
${ }^{41}$ Goffman, "Izmir," 128.

${ }^{42}$ See Feldman, Music of the Ottoman Court, 16-17.

${ }^{43}$ E.g. Damianakos (1995); Georgiadis, Rebetiko and Politics, 41-47.

${ }^{44}$ Quoted from the text of a lecture on rebetiko Hadjidakis gave on January 31, 1949, at the Athens Art Theatre. The complete Greek text plus an English translation can be accessed at <www.hadjidakis.gr>.
} 
oratorio" Axion Esti (1964), a pioneering work that demanded a buzuki player to perform together with a symphonic orchestra.

The efforts of Theodorakis and his colleagues bore rich fruit on Greek university campuses. Inspired by Bithikotsis' nearly simultaneous recordings of the Epitaph and rebetiko songs by the then half-forgotten Markos Vamvakaris, students began to rediscover the last living musicians of Piraeus rebetiko from the early 1960s onwards and became their new disciples. ${ }^{45}$ In the 1970 s and 1980s, when the rebetiko revival was in full swing, they supplied the market with a snowballing community of young amateur musicians. Until today rebetiko is an almost obligatory part of the life of most Greek students. While the common run of people prefers modern kinds of popular music, rebetiko seems now to belong to an intellectual (versus a social or ethnic) periphery. It has become a marginal phenomenon in a new sense. The same is true of Istanbul, where more than a few members of academia embrace the music of the Rum-along with that of other ethnic minorities like Armenians, Kurds or Sephardic Jews. One need only study the program of a recent musicological conference with the rather unspecific title Representation in Music \& Musical Representation (Istanbul Technical University, October 6-8, 2005) to understand what I am saying. Of the 45 papers read by Turkish musicologists more than one quarter were dedicated to the music of various groups within Turkey which were or are marginalized due to their ethnicity (Roma, Rum), gender (women, homosexuals, eunuchs), or confession (Alevi). (The fact that the opening speech of the conference was preceded by a rendition of the Turkish national anthem-following the example of everyone else, I rose to my feet-stood in wonderful contrast to its rather broadminded agenda. Not quite what someone believing in the ideal of impartial, disinterested science would expect; but a clear sign of the pride the State takes in displaying its ability to be tolerant by supporting such events.)

An important aspect of this intellectualization of rebetiko is the support it receives from leftist circles in both countries. Two out of three radio stations in Istanbul and Athens that broadcast programs dedicated exclusively to rebetiko, belong to the Left (namely the non-commercial Açık Radyo and the Athens-based Aristera sta FM which is affiliated with the Greek Communist Party KKE). The annual festival of the Greek Communist Youth KNE on the campus of the University of Athens always features prominent rebetiko singers. Finally, the record company Kalan Müzik in Istanbul which produced two CD anthologies of old rebetiko recordings represents a similar political orientation. ${ }^{46}$ In Turkey, the Kalan label has a legendary repute thanks to its releases of a great variety of albums dedicated to the music of ethnic minorities, especially that of Kurdish epic singers $(\operatorname{ass} ı k)$ which has become associated with leftist politics. Activists in both countries have even been able to cooperate on a musical level, as in the case of an amateur ensemble of young rebetiko musicians from Athens who visited Istanbul in 1982 in order to represent the Greek Left musically and politically at the anniversary celebration of a Turkish left-leaning journal. ${ }^{47}$

\footnotetext{
${ }^{45}$ See Georgiadis (2005); Vamvakaris Autobiography (1978), 237.

${ }^{46}$ 1994, 1996; both edited by Muammer Ketencoğlu.

${ }^{47}$ Personal communication with the ensemble's buzuki player, February 4, 2005.
} 
Perhaps I should point out that it is misleading to talk about "the leftist intellectual" in the singular when discussing leftists' attitudes towards rebetiko because in both countries the Left was, and is, highly fragmented. Let me try to outline what I think the crux of the matter is. Comparable historical processes lead, in Greece as well as in Turkey, to a transformation of the Left. Before the 1980 coup d'état in Turkey, violence between right-wing and left-wing militants had been an everyday occurrence, thus rousing public antipathy towards political extremism. During the subsequent military regime under Kenan Evren the more radical leftists were either imprisoned or left the country. A similar development had forced Greek communists into exile when in 1967 a military junta took control of the country. In addition to those experiences, left-wing parties adhering to a rigidly Marxist approach had to face an identity crisis as this theory no longer squared with recent political and social developments, above all the breakdown of Communist regimes in 1989. These factors contributed to a marginalization of radical leftism and to the rise of moderate and reform-minded left-wing groups, a large number of which were formed to advance causes that had nothing to do with "class struggle" (e.g., environmentalism, world peace, rights of ethnic and social minorities, dialogue between political and religious leaders). And they recruited their members from a changing middle class that had been diversified with the growing internationalization of both economies since the early 1980s. Interest in popular culture and indigenous musical traditions (songs of the aşık, early rebetiko and other forms of folk song) was a key characteristic of some of these newly emerging groups.

In consideration of these facts, it is definitely correct to say that rebetiko almost concomitantly won the approval, if not the hearts, of many leftists in both countries. There is one respect, however, in which their viewpoints on the matter are diametrically opposed. In Turkey, pluralism, ideological tolerance, and social equality-in short, a "peaceful coexistence of differences"-were among the main themes of intellectual debates throughout the 1990s. ${ }^{48}$ As already suggested, the current popularity of the music of Turkey's ethnic minorities and the notion of Ottoman multiculturalism has to be seen in this context. While also being high on the agenda of Greek activists, the above issues did not bear on their attitude towards rebetiko: for this music had already been officially recognized as a part of the national heritage. Especially during the 1980s the socialist PASOK government patronized rebetiko artists in various ways, thereby giving, as it were, "a state funeral to the myth of rebetika as 'anti-art,' 'art maudit' and to the myth of the rebetis as nonconformist or enemy of the establishment." Widely understood to exemplify the rather conservative idea of "the spirit of the Greek people" as a challenge to Western hegemony, rebetiko retained, however, a sense of marginality and insubordination on an intercultural level. In Turkey, on the other hand, it took the form of a symbol of ethnic diversity which in spite of its retrospective tendencies indicated a progressive way of thinking in comparison with Kemalism.

It isn't a matter of course that the intelligentsia conferred such honorary titles on rebetiko. Over a long time, many educated Greeks had denied rebetiko was in any way related to the arts. Indeed, they had never tired of condemning it as "mean," "corrupting," "criminal," "Asiatic," or otherwise uncivilized. In 1934, the Istanbul-born music critic Sofia Spanudi, one of the earliest and

\footnotetext{
${ }^{48}$ Akdeniz (2004).

${ }^{49}$ Gauntlett, "Orpheus in the criminal underworld," 36.
} 
most ardent accusers of rebetiko, had warned against these "low, vulgar and earthy" songs from "Anatolia" which would "drag the art of music down to the filthiest levels of obscene musical writing." ${ }^{50}$ And thirteen years later, amid the turmoil of the Greek Civil War, leftist composer Alekos Xenos complained about "the evil caused by the sickly atmosphere of the drug-related, pornographic rebetiko songs" which had been "made out of melodic bits and pieces left behind by the Turkish conqueror" and were "sung amongst those strata the pauperizing economic policy of capitalism had reduced to utmost poverty." ${ }^{51}$

Astonishingly, however, it is not so much the rhetoric that has since changed as the target for leftist criticism. A good number of Greek and Turkish intellectuals today appreciate rebetiko, while they frown upon certain forms of contemporary popular music using the same pejorative epithets which once were reserved for the former. It is Turkish arabesk and Greek skiladhiko that comes to mind. The oft-repeated slogan of "compliance with the system" is a case in point. A columnist of the Greek newspaper Eleftheri Ellada ("Free Hellas"), for instance, wrote in 1946 that rebetiko songs “are neither anarchic nor are they aimed at overthrowing 'the well and healthy regime.' And since they are not aimed at overthrowing it, they are naturally aimed at preserving it"-by promoting drug use and thus putting potentially revolution-minded people "out of action." A few decades later, many leftists had accustomed themselves to the idea that (contrary to former teachings) "rebetiko is nothing but the expression of the collective artistic potentialities of the oppressed subproletarian strata [...] which besides being revolutionary in ideological terms, does also have a national form and a content related to social class. ${ }^{{ }^{52}}$ Then, they directed their verbal attacks against a new musical threat. In 1982, the journal Odhiyitis ("Leader"), mouthpiece of the KKE, published an interview entitled "The decay of the popular song" wherein a top executive of a big record company claimed that the unimpeded promotion of skiladhiko, "a [type of] lumpen love song that talks complete nonsense," led to "the corruption of the youth," all the more so as "this genre is still being listened to by people concerned about social issues, too." In a similar vein, an article published in 1994 in the radical left-wing journal Kurtuluş Cephesi ("Liberation Front") stormed at the current "domination of lumpen arabesk culture," which had begun to creep even into the more "populist" publications of the Turkish Left, and proclaimed that only education-not mass appeal-provided the means for helping ordinary people develop a "revolutionary awareness." 53

It could be argued that some special quality which rebetiko has and skiladhiko and arabesk lack, accounts for the fact that many intellectuals today accept the former (and only the former) as a "proof that we have culture," to quote the Greek painter Yannis Tsaruchis. ${ }^{54}$ These genres differ, to

\footnotetext{
${ }^{50}$ In the Greek newspaper Athinaika Nea, November 10, 1934.

${ }^{51}$ From a letter published in the leftist newspaper Rizospastis, February 4, 1947. On the rebetiko controversy in the Greek Left press see Vlisidis, Aspects of Rebetiko, 67-164.

${ }^{52}$ Pavlos Pelayitis (1976).

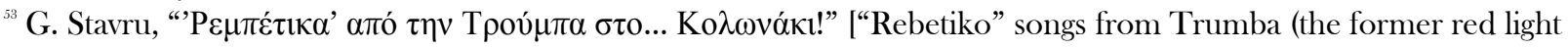
district of Piraeus) to... Kolonaki (a posh part of Athens)], Eleftheri Ellada, November 27, 1946; P. Pelayitis, book review

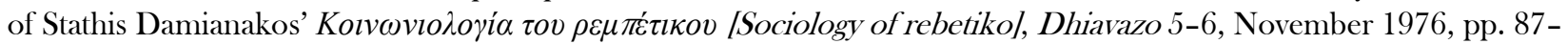

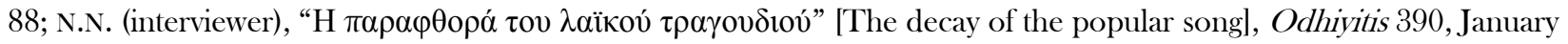
28, 1982, p. 20; N.N., "Sol Yayınlarda Popülizm Ya da Lümpen-Arabesk Kültürün Egemenliği” [Populism in Leftist Publications or the Domination of Lumpen Arabesk Culture], Kurtuluş Cephesi 19, May-June 1994.

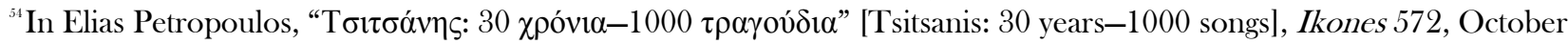
1966, pp. 33-37, reprinted in Petropoulos, Songs of the Greek Underworld, 256-259.
} 


\section{Music AND Politics Winter 2008}

be sure, in many ways. Yet as far as musical and poetic style are concerned, one can neither deny the existence of evident similarities between them. Arabesk, a type of song drawing on Turkish folk and art music as well as Egyptian and Western popular music, emerged in the 1960s and 1970s and gained immense popularity among poor rural immigrants who had settled on the fringes of Istanbul. The Greek song genre often labeled skiladhiko developed, roughly during the same period, out of the popularized branch of rebetiko. In terms of instrumentation, rhythmic and melodic patterns or poetic imagery, rebetiko and skiladhiko have thus several common features. But skiladhiko also absorbed elements of popular songs from India, Turkey and the Arab world which began to be disseminated in Greece from the mid-1950s; and, like arabesk, it was later influenced by Western rock and disco music. ${ }^{55}$ All three genres are, in short, products of the eclecticism so characteristic of Levantine popular music in general.

Apart from musical aspects, the commonalities between rebetiko, skiladhiko, and arabesk also concern the song texts which are centered round topics of heartache, loneliness and injustice treating them with a melancholic, rather egocentric introspection that often claims alcohol or hashish to be the only way of escaping from an otherwise hopeless situation. ${ }^{56}$ During their vocal interpretation, singers often make use of the microtonal melodic intervals, inflections, and embellishments of makam-based music to signal irrational, usually erotic, passions. This specific manner of singing is in both the Turkish and the Greek language described with words implying combustion. Arabesk is ideally sung in a yanı ("burnt," passionate) fashion, while skiladhiko demands a delivery characterized as kapsuriko, an adjective deriving from kapsa which means extreme heat as well as an overpowering sexual desire. ${ }^{57}$ What is more, several emotive keywords that recur numerous times throughout the corpus of arabesk lyrics can be found in many rebetiko and skiladhiko songs as well: for example sevda-sevdas ("passion”), dert-derti ("sorrow"), hasretkaïmos ("yearning"), felek-mira ("fate”), yalan dünya-pseftis dunias ("false world"), or gurbetkurbeti (“foreign parts").

\begin{tabular}{llll}
\hline $\begin{array}{l}\text { Scores of items on the scale worthless:valuable } \\
\text { (1=absolutely worthless, } 7=\text { highly valuable })\end{array}$ & mean \\
\hline & song 1 & 4.6 & \\
& song 2 & 5.3 & \\
rebetiko songs & song 3 & 4.8 & 5.0 \\
& song 4 & 4.4 & \\
& song 5 & 5.3 & \\
generic term & song 6 & 5.8 & \\
\cline { 2 - 4 } & arabesk & & 2.0 \\
\hline
\end{tabular}

TABLE 4 Ratings of the generic term arabesk and of six stylistically and thematically diverse rebetiko songs by listeners in Istanbul $(\mathrm{n}=18)$.

\footnotetext{
${ }^{55}$ See Abatzi and Tasulas (1998).

${ }^{56}$ It should, however, not be lost on us that the similarities often end when one examines the beliefs expressed or implied in the lyrics. The latter convey ideas about manhood, the opposite sex, love or family life that can vary significantly from genre to genre. For more information see Economu (1991) on skiladhiko, Stokes (1992), 120-23 on arabesk and Spiridaki (1996) on rebetiko.

${ }^{57}$ Stokes, The Arabesk Debate, 136.
} 
A thorough stylistic and sociological comparison of these genres is well beyond the scope of this article. It is clear, however, that given the aforesaid similarities, the discrimination in favor of rebetiko can hardly have been made on grounds of music, verse or working-class pedigree alone. Furthermore, it is nothing unusual to hear one or two rebetiko classics during a night at a skiladhiko club. Why, then, are rebetiko on the one hand, arabesk and skiladhiko on the other, evaluated in such contrasting ways (as the results indicated in TABLE 4 clearly show)? Once I asked a Greek friend of mine, who liked both rebetiko and skiladhiko, to describe a typical rebetiko fan. His illuminating reply was:

I'm sure that people who are fans of rebetiko wouldn't go to a skiladhiko club. But those who go to skiladhiko clubs might go to rebetadhika, too. [For rebetiko fans] an overemotional line, like "You left me and now I just pine away and die," is good if sung by Markos Vamvakaris; but when Plutarchos [a successful Greek pop vocalist of the younger generation] sings exactly the same words it's awful. I mean, these people [who love rebetiko] are a little dogmatic. Now that we're discussing the matter, I feel that the typical rebetiko fan may be something of a leftist. Perhaps because the Left articulates some kind of resistance to the Western [i.e. capitalist] way of thinking, living, eating, dressing and so on. ${ }^{58}$

In addition, I noticed that rebetiko enthusiasts in Athens and Istanbul considered arabesk and skiladhiko to sound significantly more "oriental” than rebetiko, which seemed a rather balanced mélange of East and West to them. But what is worse, both arabesk and skiladhiko are perceived to bear the markings of the immorality, bad taste and mindless consumerism of "the masses." They become "worthless" as they penetrate through established aesthetic and social distinctions. "Levantine pop trash," we read in a recent anthropological treatise, "is not a bad description of what is booming out of the speakers" of "the average Greek bar, radio, disco, and nightclub." ${ }^{59}$ One would not say this of rebetiko, which preserves its exquisiteness by remaining a minority phenomenon-even if it does so in an age when discussing minority phenomena has become a profitable pursuit, as the case of Istanbul shows where a multinational music industry, the Greek Orthodox heritage, the détente of Greek-Turkish relations and a growing weariness of ethnocentric historiographies all contributed to a renewed interest in this musical tradition.

What is important, therefore, is that we understand that rebetiko, unlike arabesk and skiladhiko, underwent a "cultural shift," inasmuch as it has been revalued by educated individuals in the middle and upper sectors of society, many of whom are in favor of social change. Instead of conceiving of this development as a succession of different stages in a supposed "life history" of rebetiko-from birth over adolescence, maturity, decay, and death up to its revival-the evolution of this genre is perhaps better construed as a process of relocation in conceptual space; or, to include the agents of this relocation (listeners, commentators, musicians) in our analysis, within what Pierre Bourdieu called the "space of social positions and lifestyles." This process is represented in Figure 1 , the accuracy of which has not been tested empirically as it is nothing more than a rough-andready illustration of my use of the term relocation. It should be noted that the object of this

\footnotetext{
${ }^{58}$ May 21, 2005.

${ }^{59}$ Holst-Warhaft, "Politics and popular music," 319.
} 
relocation is not a growing but one and selfsame corpus of songs (in the sense of an ageing individual) but, as the quotation marks in the next paragraph indicate, a concept that has been constantly redefined and reconnected with variable sets of musical stimuli. (The lack of space prevents me from giving a detailed explanation of the meaning of "conceptual space." Suffice it to say that this spatial metaphor is based on an idea Ludwig Wittgenstein put forward in his Tractatus Logico-Philosophicus, 3.1431, namely that "The essence of a propositional sign is very clearly seen if we imagine one composed of spatial objects [such as tables, chairs, and books] instead of written signs. Then the spatial arrangement of these things will express the sense of the proposition.”)

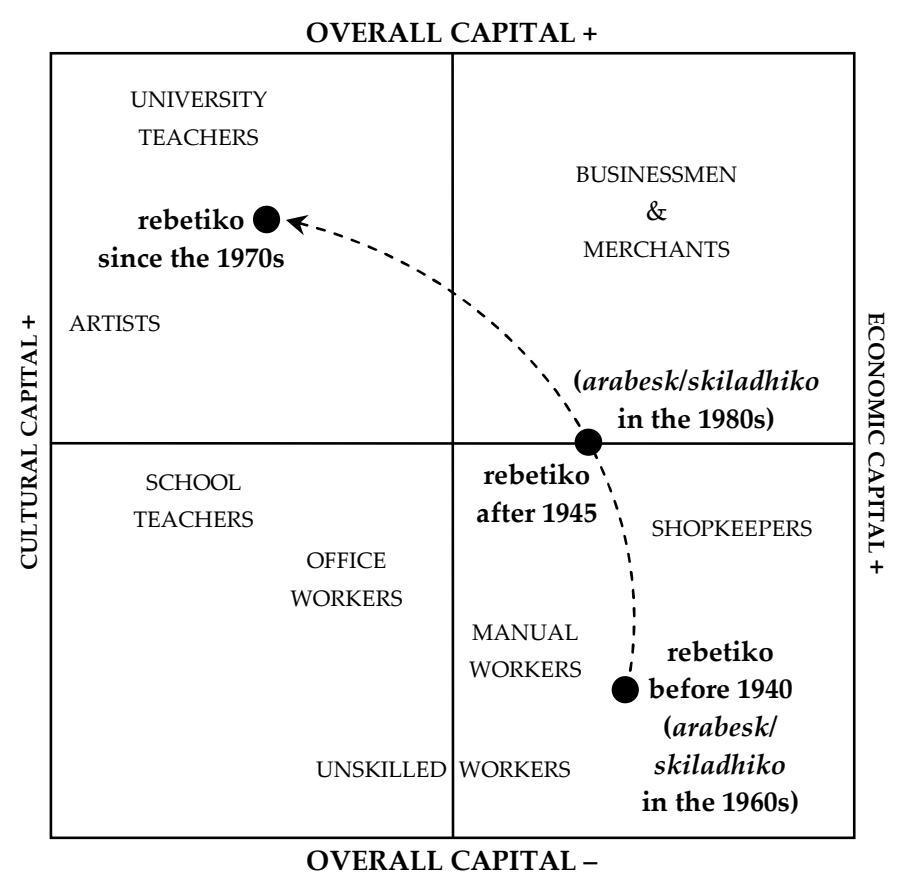

Figure 1. The relocation of rebetiko in Bourdieu's "space of social positions and lifestyles" (after Bourdieu 1984:128-29, 452). Up to Ww2, rebetiko was the music of poorly educated, poorly paid city dwellers. After the War, it became popular in economically more affluent circles-which is roughly where arabesk and skiladhiko are located since the 1980s. In the 1970s, a "cultural shift" took place as rebetiko was embraced by more and more individuals owning above all "cultural" capital and tending towards an electoral behavior in favor of left-wing parties (students, artists, university teachers). What is more, rebetiko had by then ceased to be a form of mass entertainment.

The diagram (Figure 1) indicates that during the interwar period, establishments where "rebetiko" was played were mainly frequented by people whose standard of living and level of education were rather low. Accordingly, the dot designating the social position of "rebetiko" listeners in the 1930s is close to the lower margin of the diagram. After the Second World War, more and more better off city dwellers made "rebetiko" the form of recreation of their choice, and others who already enjoyed this type of music moved up the social ladder. In the diagram, this development is represented by a broken line along which the dot "moves" towards the horizontal axis in the middle. In the 1950 s and 1960 s, the genre called "rebetiko"-if we are permitted to hold on to the term-gradually mutated into new types of popular music, among them "skiladhiko." At this point, pre-war "rebetiko" could be rediscovered, or rather appropriated, by intellectuals who now saw fit to be diverted by this music that was no longer consumed by the masses. Moreover, it 
acquired a sense of political subversiveness during the 1967-1974 military dictatorship (an issue treated in more detail below). Metaphorically speaking, "rebetiko" was pulled leftwards, as implied by the curvature of the broken line in the diagram. In contrast to this, "skiladhiko" was then about to become synonymous with a "vulgar" and "commercialized" form of mass entertainment. "The suffering of the disadvantaged," one of rebetiko's pet subjects, "faded into insignificance in the reign of the junta that witnessed a feast of economic growth and upward mobility, the phantasmagorical spectacle of the new mass media [i.e., television] and the debut of skiladhiko." ${ }^{60}$ Since the mid1970 s, arabesk went through a similar process of commercialization, especially after 1983 when it was promoted by the neoliberal Özal government for populist reasons. ${ }^{61}$ Having thus profiteddirectly or indirectly-from conservative, right-wing policies, both genres were unacceptable to individuals with leftist views.

My illustration should, of course, be treated with caution. To put it bluntly, it is reductive in that it depicts, using a single two-dimensional frame, the evolution of three musical genres and two societies over a fairly long time span. Furthermore, it presents the relocation of rebetiko in a somewhat idealized manner, because one thing is for sure-neither in Greece nor in Turkey was the comeback of this music independent of government policies and big business. I have already mentioned the Greek State's sponsorship of rebetiko artists in the 1980s which helped create a lucrative market for a whole branch of the national entertainment industry (club owners, record producers, music journalists, film-makers, etc.). In Istanbul at the end of the twentieth century, the multicultural past in general, and rebetiko in particular, became marketable too, while the government began to provide financial support for minority-related festivals and research projects. "But so what?" asked one of my Istanbul informants, a 27-year old sociology graduate. "Now multiculturalism is in vogue all over the world. [...] Why wasn't anybody interested [in ethnic minorities] in the sixties or seventies? These people would still live [in Istanbul] if we had been interested then." ${ }^{{ }^{2} 2}$ My guess is that in Greece as well as Turkey, the renaissance of rebetiko could reach sizeable proportions only when political decision-makers realized that it was, in fact, highly profitable to invest in a historical musical form which they had so far perceived as a potential threat or, at best, considered to be of little account. A multicultural trend and an interest in sub-national identities have been manifested since the 1970s in global markets of ideas and their various materializations such as music, books or scientific conferences. By promoting once marginalized, sometimes even outlawed songs, both the Turkish and the Greek government improved their countries' competitiveness in these markets and, not least, their own public image.

We are now in a position to appreciate what the unique case of rebetiko in Turkey is like. Reimported from Greece in the 1990s, it had never ceased to be the music of people whose beliefs and lifestyle placed them outside the mainstream of Turkish politics and mores. In the old days, it used to entertain the often non-Muslim lower-class customers of Pera's wine bars; today it appeals to those with a rather cosmopolitan outlook who are attracted by the notions of multiculturalism and, perhaps, permissiveness associated with rebetiko. But it has never really caught the interest of

\footnotetext{
${ }^{60}$ Economu, Affinity and Love,” 60.

${ }^{61}$ Özbek, “Arabesk Culture,” passim.

${ }^{62}$ Interview, March 8, 2005.
} 
the populace at large, as was the case in Greece before the 1960s. Thus, I propose we distinguish between various types of "nonconformist" middle-class intellectuals with a penchant for rebetiko, not only by fixing their positions on the coordinates of space and time but also by clarifying what exactly it is they do not wish to conform to. Three basic categories emerge that I will sketch-for the sake of simplicity and at the risk of making things seem less complicated than they are-in rather crude terms:

- The dissident. Prevalent in Greece in the 1960s-70s, the dissident rebetiko fan strongly opposed the Establishment (government, bourgeoisie) and the foreign powers that were known to back them. More often than not, he or she was ideologically oriented towards or even actively involved in leftist politics.

- The traditionalist. This type took shape when Greek domestic affairs ceased to be dominated by an extreme left-right polarity, namely since the 1980s. Though not necessarily interested in party politics, the traditionalist rebetiko fan is highly critical of imported fashions, especially Western mass culture which makes its presence increasingly felt since Greece's joining the European Community in 1981.

- The multiculturalist. Rebetiko fans of this kind have come to the fore in Turkey in the 1990s. They combine nostalgia for Ottoman culture with a dislike for nationalist policies and views, but their attitudes are often more or less apolitical.

To sound a note of warning, these basic categories should neither be regarded as mutually exclusive nor, if taken together, all-encompassing. Some rebetiko fans do not fit into any of them, others into more than one. Several of my consultants in Athens and Istanbul agreed, for instance, that rebetiko referred to "a time when money did not mean everything." Despite the fact that modern Greek and Turkish rebetiko enthusiasts are far from wanting in terms of prestige or income themselves, they both use this musical language to give voice to their own disapproval of today's cultural mainstream and of the materialistic world view they associate with the West.

\section{Conclusion: "Vive la différence, pas la résistance!"}

Three interrelated leitmotifs recur in various contexts throughout both popular and intellectually serious debates around rebetiko, in Greece as well as abroad. The first is the notion of "hybridity" which is often considered a typically Greek quality. It implies that rebetiko is of a dual nature. "By blending European harmonies with instruments, melodies and rhythms of Asia Minor," remarked a distinguished Swiss musicologist, "rebetiko songs realized [...] a fusion of oriental and occidental elements which [...] is still characterizing Greek culture." ${ }^{63}$ The second leitmotif is "ambiguity," i.e., rebetiko's being neither fish nor fowl. There is a widely held belief that this music exhibits a "profound ambivalence" which reflects "the moral ambiguity of contemporary man, as he passes from tradition to modernity. "Finally, there is a laundry list of writers who have taken the ambiguous duality of rebetiko to indicate a rebellious streak. Abounding with words of Turkish origin, rebetiko lyrics are, for instance, deemed to be “a form of linguistic protest" against

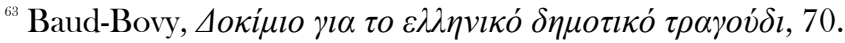

${ }^{64}$ Fatouros, "Night without moon," 27.
} 
nationalist ambitions to purify the modern Greek language..$^{6.5}$ Thus, the third leitmotif I want to discuss here is the concept of "deviance" from or "resistance" to certain norms, ideas or trends, as which the (musical, moral, emotional, semantic, cultural, etc.) polarity of rebetiko is often translated.

Numerous debaters have been fascinated by the tale of the so-called "Greek blues" being, as a typical statement illustrates, "the song of protest against the values of the dominating capitalist society. " At least two political factors contributed to the perpetuation of this myth: first, the censorship imposed on rebetiko recordings by the Metaxas regime in 1937 and maintained, in varying degrees of rigor, by subsequent governments; second, the previously discussed "appropriation" of pre-war rebetiko by leftist students. ${ }^{67}$ Both factors combined when the junta of 1967-1974 tightened up the screws of censorship just the moment rebetiko had won growing support by young dissidents. The genre had become politicized. Hence some commentators think it is fair to assume that rebetiko has an "ideological function" which is anti-authoritarian or, more abstractedly, "anti-structural." ${ }^{68}$ In their eyes, it even looks as if this rebellious attitude still makes rebetiko attractive to people who believe it to offer a relief of the conformity caused by modern mass entertainment. "In our turbulent times with their real and apparent crises of values and visions," columnist Panos Geramanis reasoned as the twentieth century drew to its close, "the songs of rebetiko, plain but rich in content, are a way of opposing and resisting all forms of establishment."

Considering the lifestyle of many older rebetiko musicians, fascination for the "subcultural" qualities of this genre is certainly proper. But overlooking the facts is not. It would, for example, be naive to underestimate the impact of the music business on the evolution of early rebetiko. Regardless of how loudly journalists in the 1930s denounced these songs, they were then already recorded for "mass" consumption, as an examination of the pre-war discography of Greek popular music reveals. ${ }^{70}$ The fact that many drug-related rebetiko songs were re-recorded with different interpreters, some as often as six times, is indicative of their extraordinary popularity-and thus profitability. According to the estimates of prominent Greek record collectors, eight to fifteen percent of the songs with references to hashish use recorded or publicly performed prior to World War II, had even been created by classically trained composers. ${ }^{71}$ Such quantitative evidence should not be accepted uncritically. Yet it casts serious doubt on the assumption that hashish songs being

\footnotetext{
${ }^{65}$ Holst-Warhaft, "Resisting translation," 191.

${ }^{66}$ Quoted from a letter by composer Stavros Xarchakos that the Greek newspaper Ta Nea published on June 9, 2003. It was also Xarchakos who had written the soundtrack for the aforementioned film Rembetiko (1983) by Kostas Ferris.

${ }^{67}$ See Vlisidis, Aspects of Rebetiko, 11-65.

${ }^{68}$ Sarbanes, "Musicking and Communitas," 30.

${ }^{69}$ In an article on "Rebetiko in the 21st century," Ta Nea, July 24, 1999.

${ }^{70}$ Cf. Strötbaum (1992); Kaliviotis (2002).

${ }^{71}$ Maniatis, The Grammophone Era, 249; Kunadis, "Hashish songs," 54. Maniatis (p. 249), counted 181 rebetiko songs with references to hashish that were recorded in Greece up to 1937, the year censorship of such songs was imposed. These songs were written by 44 composers, 11 of whom he labelled as evropaïstes ("Europeanists"), i.e. musicians trained in Western classical music. The evropaistes wrote, he claimed, 14 of these 181 hashish songs (7.7 percent). According to Kunadis, "Hashish songs," 54, the number of drug-related Greek popular songs from the pre-1937 era-including those of oral tradition most of which have never been recorded-approximates 600. He contended that the European-style composers had created nearly 100 of them (roughly 15 percent), often intended as parodies of rebetiko songs for revues.
} 
accounts of personal experiences of their authors or reflecting the habits of their audiences were the rule.

It is another seldom recognized fact that a number of these songs contain irony or are outright parodies, that is, they reveal the narrator's true intentions only to those "in the know" thereby, in effect, "hindering the [uninitiated] reader [that is, us] from making moral or sociopolitical judgments. ${ }^{\text {72 }}$ Rather, the wry humor peculiar to rebetiko, which as often as not satirizes the rebetes themselves, the tongue-in-cheek complaints about female coquetry, male braggadocio, the arbitrary powers of police officers, or certain social conventions of the time reveal, first, an ambivalent attitude towards both mainstream society and rebetiko culture, and second, a desire to play, to entertain, to create a conspiratorial feeling of togetherness-in a word, a state of "being amused at inconsistencies." ${ }^{\text {`3 }}$ This polysemy brings into question the theory of rebetiko as an expression of contempt for bourgeois values, tastes, and institutions (which more or less rules out the possibility of rebetiko lyrics being perceived as funny) by undermining the credibility of its central tenet, namely that the rebetes were honest, innocent but subversive by nature. "The grin of rebetiko will always stay on to remind us that there is something more, that no single symbolic interpretation of social life can define the social subjects exhaustively, however dominant it may be in their narratives." ${ }^{74}$

Inspecting rebetiko, even in its classical days, solely through the lens of an "uncategorizable musicking subculture" (Sarbanes) is therefore, in my view, insufficient. The issues raised in this study suggest that our difficulties in classifying rebetiko do not stem from any inbuilt "uncategorizability" but rather from the multitude of viewpoints from which this music has so far been looked at. I have no hesitation in admitting that rebetiko, like many other generic terms, is a dazzling but dubious concept. It resembles skiladhiko or arabesk not least in its being "an ambivalent term composed of multiple meanings that are manipulated by distinctive groups for strategic effect." ${ }^{95}$ Given its elusiveness, it would thus be all too easy to repeat the slogan of rebetiko as a "standard of revolt" against hegemonies of all kinds, including our own scholarly attempts at its categorization. ${ }^{76}$ However, the doctrine that rebetiko was and is always sung by people resisting-e.g., the police, totalitarian governments, Western mass culture, language reforms, Stealth Fighters, or scientific analysis-seems a rather Procrustean one, that is, a theoretical condition we impose on reality by way of making her fit our preconceived ideas. And it is an irony that so irresistibly rebellious a music as rebetiko is suddenly unable to offer even the slightest resistance.

To deduce from its ambiguity that rebetiko is essentially Janus-faced, forever escaping classification, might have an element of truth in it. In point of fact, however, this does not stop people on both sides of the Aegean from describing rebetiko in culturally meaningful manners. In this essay I have tried to demonstrate how listeners in Istanbul and Athens indigenize and assimilate

\footnotetext{
${ }^{72}$ Païvanás, "The translatability and interpretation of rebétika,” 118.

${ }^{73}$ Vamvakas (1999).

${ }^{74}$ Vamvakas, "Humour, Irony and Ridicule," 10.

${ }^{75}$ O'Connell, "In the Time of Alaturka," 192.

${ }^{76}$ I am not shadow-boxing here, one may just read Holst, Road to Rembetika, 12-15. But this author is not alone in misconstruing polysemy as subversiveness: "In form and by definition," a study of Rastafarianism in the UK concludes, "reggae resists definition. The form, then, is inherently subversive" (emphasis added; Hebdige, "Reggae, Rastas \& Rudies," 147).
} 
rebetiko-to a certain degree-by means of relocating it in conceptual space. They define rebetiko as the music of a local minority, of "others that are us," that is, as a peripheral part of their own (imagined) central culture. Istanbullus relate rebetiko with Ottoman civilization; Greek commentators have a propensity toward "Hellenizing" it. ${ }^{77}$ This is in both cases, as the previous section has shown, the outcome of processes of intellectualization. In the course of these processes rebetiko came into contact with indigenous art music and the political Left which added a touch of exclusiveness to its pariah image.

Recapitulating the findings of this study, I would say that for its fans today rebetiko denotes neither otherness per se, i.e. the ethnic, social, religious or political other, nor the opposition between some kind of establishment and themselves as alienated and dissenting others. Instead, the specific "function" of rebetiko is to enable listeners to experience and become aware of another side of themselves-and thus of the intrinsic ambiguity of life. The fact that Turkish musicians have translated rebetiko songs into their mother tongue and perform them on typically "Ottoman" instruments like the ney or the tanbur seems to indicate that they, and their audiences, are both willing and able to identify with the "narrators" of these songs.

For that reason, I doubt that rebetiko has an ongoing appeal for Greek and Turkish audiences because it is excitingly "different," "untamed," or "subversive." In our days, this music is hardly valued for catering to intellectual voyeurs of the old Greek underworld and still less for a supposed tone of disobedience, as those theories imply which define rebetiko as defiant, uncategorizable, anti-structural and the like. The main problem of such "non-compliance theories," as they might be labeled in a somewhat sweeping manner, is that they presuppose not only the existence of hard and fast rules, laws and norms imposed by an identifiable Establishment, but also the awareness that such rules etc. exist and should be complied with. Moreover, those who oppose the Establishment by definition form an anti-Establishment-which is a kind of establishment nevertheless. This, I feel, results in an overly antagonistic black-and-white picture of society: one consisting of polar opposites, the first of which is the ruling and the second the revolting one (us-them, West-East, global-local, traditional-avant-garde, bourgeois-proletarian, to name only a few). Notions like "subversion" or "resistance" should, of course, not be dismissed out of hand because they have proved useful for explaining how certain rebetiko songs were understood in certain historical contexts. Nor do I suggest abandoning conceptual opposites as such which continue to exist as categories of thinking. My intention is to alert those who study rebetiko and related phenomena to the harmful effects of an overgeneralization of such concepts, lest a misleading, one-sided view of (Greek) culture as a permanent struggle between distinct opponents result.

Alternatives to these dualistic approaches exist within musicology, as well. Scholars have begun to argue persuasively in favor of a polyphonic understanding of music-making in multicultural societies as a way of interaction between several disparate, coexisting systemic components of equal importance (however these may be defined in practice) that engage in a concertatio, a musical dispute or contest. They may compete with but ultimately complement, rather than exclude, each other. Through their interaction, they contribute to maintaining the equilibrium of the whole system-and not to increasing the prestige of one side of an opposition at

\footnotetext{
${ }^{77}$ See Pennanen (2004).
} 
the expense of the other, which is then forced into acting the role of the outsider, the rebel, the member of a sub-culture. ${ }^{78}$ Such contrapuntal models can account for the fact that man-especially the homo musicus-makes multiple, hence ambiguous, sense of the world and the self, without evoking the idea of a clash between the resultant "constructions." Vassilis Lambropoulos (2001) has explored the notion of syncretism as a conceptual device for construing intercultural mixing processes from this point of view. "Unlike hybridity, which can regress into an apotheosis of creole cultures and cross-breeding,” he wrote,

Syncretism does not glorify otherness but rather features competitive encounters of heterodoxy. [...] Working without an oppositional logic, it may not possess the allure of resistance, of antihegemonic struggle that theories of the subaltern exercise. [...] The notion of syncretism retains the specific dynamic of inconsistencies or contradictions without either radicalizing or homogenizing the blending. It is the notion's capacity to contain polyphony and draw attention to moments of inconclusive fusion that make it a useful tool for analysis. ${ }^{79}$

One could argue that by invoking this theory I simply suggest to replace one ideologically biased view with another, namely the "Greek" understanding of rebetiko as a form of resistance with the "Turkish" reading of it as a product of Ottoman pluralism. This, however, is far from the case. I do not claim we had to come down on one side of a paradigmatic fence or the other. Rather, situations such as fight for domination or peaceful symbiosis should be conceived of as just two among many possible outcomes of syncretistic processes.

Let me, by way of conclusion, inject a constructive note into my critique and offer a different explanation of the resurgence of rebetiko in the light of the evidence this study has yielded. First, a historical point needs to be made. Once the capitals of great and powerful civilizations, both Athens and Istanbul had to face decline and henceforward have been leading an existence on the periphery of Europe-a humiliating thought for not a few of their inhabitants. In the tenth chapter of the homage he wrote to his native town, Orhan Pamuk elaborated the argument that it is precisely this idea of loss and decay that infused twentieth-century Istanbul's music with an all-pervading sense of hüzün or "sadness." And it might not be a coincidence that in both cities rebetiko enjoyed its comeback at a time when each nation had just entered a new phase of political and economic prosperity: Greece after 1974, Turkey around 1990. No longer torn and isolated, both countries had, generally speaking, managed to produce modern, democratic, and pluralistic societies with growing numbers of educated, wealthy citizens. Theoretically, the time had come for the latter to prove they were worthy of being the heirs of their glorious ancestors. Yet the cherished national myth of an innate superiority, deeply ingrained since the days both countries developed into independent nation states, turned out to be just that: a myth. Neither nation could impress the world with amazing new accomplishments that raised them above the rest. So instead of being

\footnotetext{
${ }^{78}$ Let me refer to only one work that is exemplary in the wideness of its choice of examples to show that music, far from being a mere symbol of something else, provides-perhaps more than most other spheres of human experience-a means of mediation and transition between various conditions (realities, worlds, traditions, identities, states of consciousness etc.), in such a way that the functional integrity of a social system is maintained by preserving, instead of either minimizing or maximizing, the differences between them: Christian Kaden's The Unheard-of and the Inaudible: What Music Is, What Music Can Be (German language, 2004).

${ }^{79}$ Lambropoulos, "Syncretism as Mixture and as Method," 229-30.
} 
proud of what their countries have achieved (which is by no means little), many Athenians and Istanbullus remained emotionally attached to a time when it was still possible to believe in belonging to a heroic people. In other words, I want to suggest that what fuels the resurgence of rebetiko in Turkey, and arguably did so in Greece after 1974 too, is neither the intellectuals' wish to bring down the powers that be nor their hope to restore the glory that was. Rather, it is the sobering experience of waking up to a new reality and the desire to fall asleep again so as to resume the convenient dream of living "on the fringes."

It might be this common experience that lies-together with other factors like those pertaining to the problems of modern city life-at the root of the recent back-to-the-roots movements in both countries in general and of the emotional identification of Greek and Turkish audiences with rebetiko in particular, an experience that has produced feelings of disillusionment and nostalgia (or rather, of longing for a past when it still seemed legitimate to feel nostalgia) ${ }^{80}$ Perhaps the bittersweet melancholy of rebetiko, its ambivalent attitude towards society and its overall semantic ambiguity are congenial to the expression of these feelings. Paradoxical as it may sound, one of the most important reasons why rebetiko strikes a responsive chord in individuals in two countries as similar yet different as Greece and Turkey, could be its ability to give them a sense of marginality as something desirable.

${ }^{80}$ Cf. Öztürk (2003). 


\section{References}

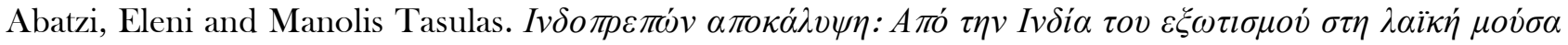

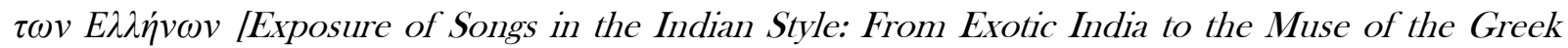
Peoplel, Athens, 1998.

Akdeniz, Eylem. "The Intellectual and the Transformation of the 'Political': An Analysis of the Metamorphosis of the Turkish Intellectual in the Last Two Decades.” Paper read at the Middle East History and Theory Conference, University of Chicago, April 30-May 1, 2004 (Accessed 9 August 2007) <http://cas.uchicago.edu/workshops/mehat/past_conferences/XIXth_MEHAT_papers/AKDENIZ.doc>

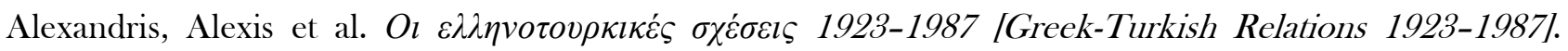
Athens, 1991.

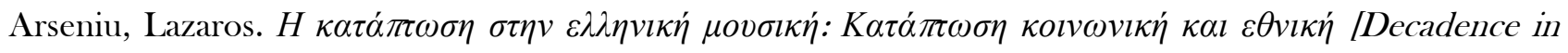
Greek Music: A Social and National DeclineJ. Larisa, 1979.

Aydin, Mustafa and Kostas Ifantis, eds. Turkish-Greek Relations: The Security Dilemma in the Aegean. London and New York, 2004.

Aytar, Volkan and Azer Keskin. "Constructions of spaces of music in Istanbul: Scuffling and intermingling sounds in a fragmented metropolis.” Revue de géographie de Lyon: Géocarrefour 78, no. 2, special issue on La ville, le bruit et le son (2003): 147-57.

Bartu, Ayfer. "Who owns the old quarters? Rewriting histories in a global era." In Istanbul: Between the Global and the Local, ed. Çağlar Keyder, 31-45. Lanham-Oxford, 1999.

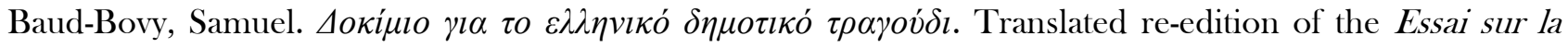
chanson populaire grecque, Navplion 1983. Navplion, 1994,

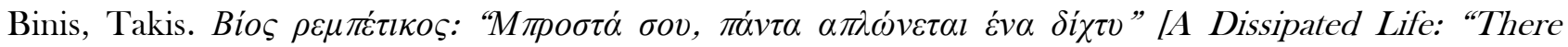
always is a net spread out before you"], edited by Ioanna Kliasiu. Athens, 2004.

Bourdieu, Pierre. Distinction: A Social Critique of the Judgement of Taste. London, 1984.

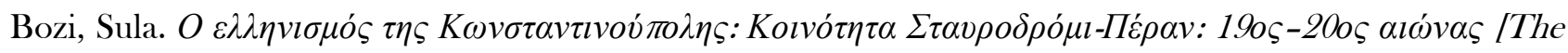
Greeks of Constantinople: The Community of Stavrodromi-Pera: 19th-20th Century]. Athens, 2002.

Butterworth, Catherine and Sarah Schneider, eds. Rebetika: Songs from the Old Greek Underworld. Athens, 1975.

Çarkoğlu, Ali and Kemal Kirişci. "The view from Turkey: Perceptions of Greeks and Greek-Turkish rapprochement by the Turkish public.” In Greek-Turkish Relations in an Era of Détente, edited by Ali Çarkoğlu and Barry Rubin, 117-53. London-New York, 2005,

Çarkoğlu, Ali and Barry Rubin, eds. Greek-Turkish Relations in an Era of Détente. London-New York, 2005.

Constas, Dimitri, ed. The Greek-Turkish Conflict in the 1990s: Domestic and External Influences. London, 1991. 
Coufoudakis, Van. "Greco-Turkish relations and the Greek Socialists: Ideology, nationalism and pragmatism.” Journal of Modern Greek Studies 1 (1983): 373-92

Damianakos, Stathis. "Du clephte des montagnes au rébète des villes: dissidence sociale et continuité des illégalismes populaires en Grèce (XVIIIe-première moitié du XXe siècle).” In Banditisme et violence sociale dans les sociétés méditerranéennes, Études Corses vol. 40/41, ed. Georges Ravis-Giordani and Ange Rovère, 121-38. Bastia, 1995.

Duben, Alan and Cem Behar. Istanbul households: Marriage, family and fertility, 1880-1940. Cambridge, 1991.

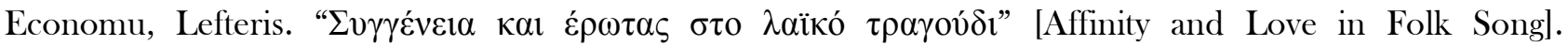
Archaeologia 41 (1991): 60-64.

Eldem, Edhem. "Istanbul: from imperial to peripherialized capital." In The Ottoman City between East and West: Aleppo, Izmir, and Istanbul, by Edhem Eldem, Daniel Goffman, and Bruce Masters, 135-206. Cambridge, 1999.

Evin, Ahmet O. "Changing Greek perspectives on Turkey: An assessment of the post-earthquake rapprochement.” In Greek-Turkish Relations in an Era of Détente, edited by Ali Çarkoğlu and Barry Rubin, 4-20. London-New York, 2005.

Fatouros, A. A. "Night without moon: Aspects of the rebetika." Journal of the Hellenic Diaspora 3, no. 4 (1976): 17-28.

Feldman, Walter. Music of the Ottoman Court: Makam, Composition and the Early Ottoman Instrumental Repertoire. Berlin, 1996.

Gauntlett, Stathis. "Orpheus in the criminal underworld. Myth in and about rebetika." Mantatophoros 34 (1991): 7-48.

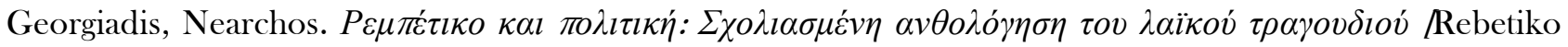
and Politics: Annotated Anthology of Popular Songl. 2nd ed. Athens, 1999.

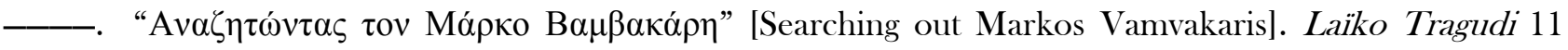
(2005): 26-38.

Goffman, Daniel. "Izmir: from village to colonial port city." In The Ottoman City between East and West: Aleppo, Izmir, and Istanbul, by Edhem Eldem, Daniel Goffman, and Bruce Masters, 79-134. Cambridge, 1999.

Hebdige, Dick. "Reggae, Rastas \& Rudies." In Resistance Through Rituals: Youth Subcultures in Post-War Britain, edited by Stuart Hall and Tony Jefferson. First published in 1976; second reprint, London, 1996.

Holst-Warhaft, Gail. "Politics and popular music in modern Greece." Journal of Political and Military Sociology 30, no. 2 (2002): 297-323.

- "Resisting translation: Slang and subversion in the rebétika." Journal of Modern Greek Studies 8, no. 2 (1990): 183-96.

Holst, Gail. Road to Rembetika: Music of a Greek Subculture. Limni, 1975. 
Kaden, Christian. Das Unerhörte und das Unhörbare: Was Musik ist, was Musik sein kann. KasselStuttgart, 2004.

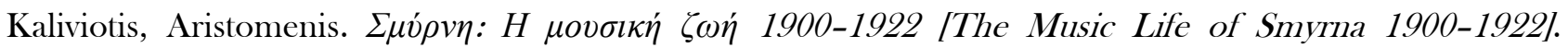
Athens, 2002.

Karpat, Kemal. "The Population and the Social and Economic Transformation of Istanbul: The Ottoman Microcosm.” In Ottoman Population 1830-1914: Demographic and Social Characteristics by Kemal Karpat, 86-105. Madison/Wisconsin, 1985.

Keridis, Dimitris and Dimitris Triantaphyllou, eds. Greek-Turkish Relations in the Era of Globalization, London, 2002.

Keyder, Çăglar, ed. Istanbul: Between the Global and the Local. Lanham-Oxford, 1999.

Kramer, Heinz. "Turkey's relations with Greece: Motives and interests.” In The Greek-Turkish Conflict in the 1990s: Domestic and External Influences, edited by Constas, Dimitri, 57-72. London, 1991.

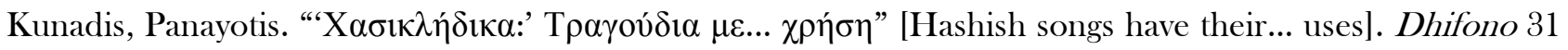
(April 1998): 50-55.

Lambropoulos, Vassilis. "Syncretism as Mixture and as Method." Journal of Modern Greek Studies 19, no. 2 (2001): 221-35.

Levy, Claire. "Who is the 'other' in the Balkans? Local ethnic music as a different source of identities in Bulgaria.” In Music, Space and Place: Popular Music and Cultural Identity, edited by Sheila Whiteley, Andy Bennett, and Stan Hawkins, 42-53. Aldershot, 2004.

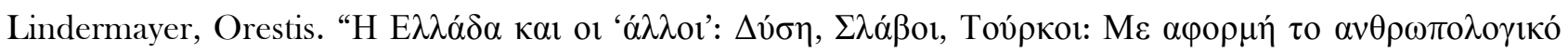

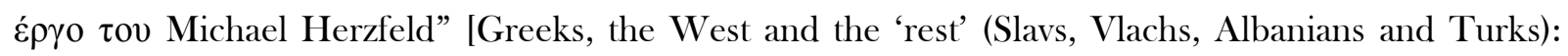
Anthropological reflections on Michael Herzfeld's work]. Ethnoloyia 6-7 (1999): 359-439.

Maniatis, Dionisis. I fonografitzídes [The Grammophone Era]. Athens, 2001.

Manuel, Peter. Popular Musics of the Non-Western World: An Introductory Survey. New York-Oxford, 1988.

Millas, Hercules. "National perceptions of the 'other' and the persistence of some images." In TurkishGreek Relations: The Security Dilemma in the Aegean, edited by Mustafa Aydin and Kostas Ifantis, 53-66. London and New York, 2004.

Monos, Dimitri. "Rebetico: The Music of the Greek Urban Working Class." The International Journal of Politics, Culture and Society 1, no. 2(1987): 301-09.

O’Connell, John Morgan. "In the Time of Alaturka: Identifying Difference in Musical Discourse." Ethnomusicology 49, no. 2 (2005): 177-205.

Örter, Erol. Buzuki Erol. Istanbul, 1998.

Özbek, Meral. “Arabesk Culture: A Case of Modernization and Popular Identity.” In Rethinking Modernity and National Identity in Turkey, edited by Sibel Bozdoğan and Reşat Kasaba, 211-32. Washington, 1997.

Öztürk, Ali Osman. “Bemerkungen zur türkischen populären Liedtradition der Neunzigerjahre.” Song and Popular Culture 48 (2003): 241-53. 
Païvanás, Dimitry. "The translatability and interpretation of rebétika." Journal of Modern Greek Studies 11, no. 1 (1993): 107-31.

Pamuk, Orhan. Istanbul: Memories and the City. Translated by Maureen Freely. New York, 2006.

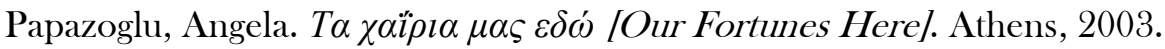

Pappas, Nicholas G. “Concepts of Greekness: The recorded music of Anatolian Greeks after 1922.” Journal of Modern Greek Studies 17 (1999): 353-73.

Pennanen, Risto Pekka. "Development, interpretation and change of dromos houzam in Greek rebetika music.” In The Structure and Idea of Maqām: Historical Approaches, edited by Jürgen Elsner and Risto Pekka Pennanen, 125-74. Tampere, 1997.

—_. "The Nationalization of Ottoman Popular Music in Greece." Ethnomusicology 48, no. 1 (2004): 125.

Petropoulos, Elias. Songs of the Greek Underworld: The Rebetika Tradition. Translated by Ed Emery. London, 2000.

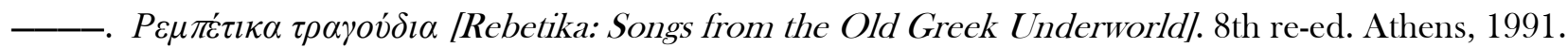

Pettan, Svanibor. "Encounter with 'The Others from Within:' The Case of Gypsy Musicians in Former Yugoslavia." The World of Music 43, no. 2-3 (2001): 119-137.

Plastino, Goffredo, ed. Mediterranean Mosaic: Popular Music and Global Sounds. New York-London, 2003.

Revault d'Allonnes, Olivier. "L’art contre la societé. Une culture dominée: Le rebetiko." In La création artistique et les promesses de la liberté, idem, 143-78. Paris, 1973.

Sant Cassia, Paul. "Exoticizing discoveries and extraordinary experiences: 'Traditional' music, modernity, and nostalgia in Malta and other Mediterranean societies.” Ethnomusicology 44, no. 2 (2000): 281301.

Sarbanes, Janet. "Musicking and Communitas: The Aesthetic Mode of Sociality in Rebetika Subculture." Popular Music and Society 29, no. 1 (2006): 17-35.

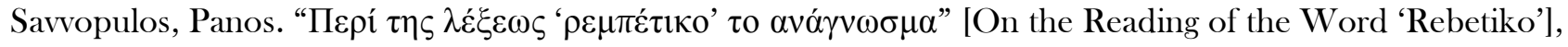
Odos Panos 131 (2006): 4-21.

Seufert, Günter and Christopher Kubaseck. Die Türkei: Politik, Geschichte, Kultur. Munich, 2004.

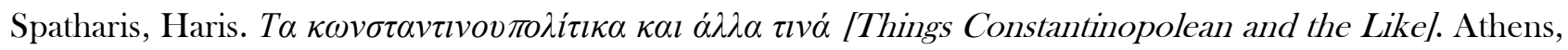
1988.

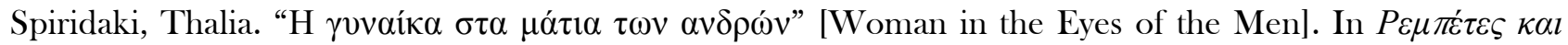

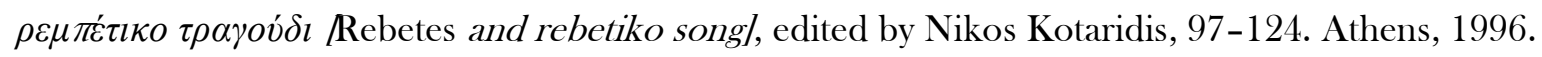

Steingress, Gerhard, ed. Songs of the Minotaur. Hybridity and Popular Music in the Era of Globalization. A Comparative Analysis of Rebetika, Tango, Rai, Flamenco, Sardana, and English Urban Folk. Münster-Hamburg-London, 2002.

Stokes, Martin. The Arabesk Debate: Music and Musicians in Modern Turkey. Oxford, 1992. 
. "History, Memory, and Nostalgia in Contemporary Turkish Musicology.” Music \& Anthropology 1 (1996) (Accessed 9 August 2007) <http://www.levi.provincia.venezia.it/ma/index/number1/stokes1/st1.htm>

- "Sounding out: The culture industries and the globalization of Istanbul." In Istanbul: Between the Global and the Local, edited by Çă̆lar Keyder, 121-39. Lanham-Oxford, 1999.

Strötbaum, Hugo. "Seventy-eight revolutions per minute in the Levant: Discography of Favorite's oriental recordings." In De turcicis aliisque rebus commentarii Henry Hofman dedicati (Festschrift Henry Franciscus Hofman), Utrecht Turcological Series vol. 3, 149-88. Utrecht, 1992.

Susam-Sarajeva, Sebnem. “Rembetika Songs and Their 'Return' to Anatolia.” The Translator 12, no. 2, special issue on Translation, Travel, Migration (2006): 253-78.

Tohumcu, Ahmet. "Bir Mekan Temsili: Taverna" [Representing a Space: Taverna]. Paper read at the International Musicological Conference Representation in Music \& Musical Representation (İTÜ, October 6-8). Istanbul, 2005.

Tragaki, Dafni. Rebetiko Worlds. Cambridge Scholars Publishing, 2007.

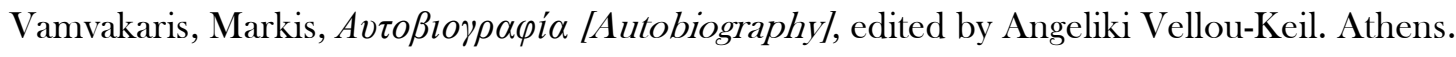

Vamvakas, Vasilis. "Xıv́

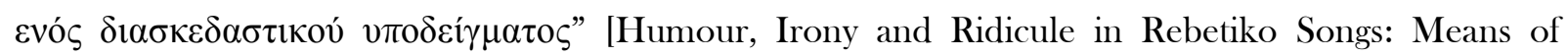
Realizing a Model for Entertainment]. Dhokimes 8 (1999): 7-53.

Van de Port, Mattijs. "The Articulation of Soul: Gypsy Musicians and the Serbian Other.” Popular Music 18, no. 3 (1999): 291-308.

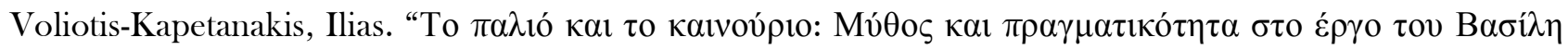

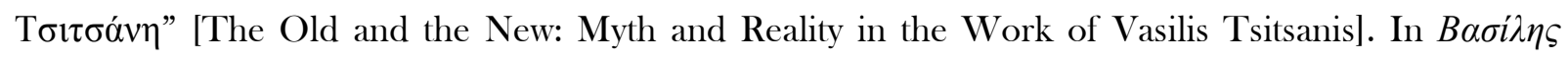

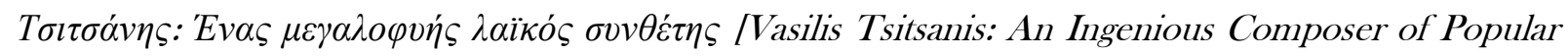
Musicl, edited by Anastasia-Valentini Riga, 33-38. Athens, 2003.

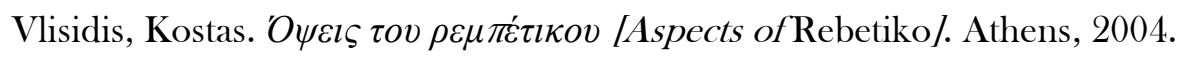

Yiallourides, Christodoulos and Panayotis Tsakonas, eds. Greece and Turkey After the End of the Cold War. New York-Athens, 2001. 


\begin{abstract}
At its outset, Greek rebetiko song had been a disreputable genre inasmuch as many intellectual opinionleaders associated it with urban lowlifes and Turkish music. Today, however, members of the educated classes-in Greece as well as in Turkey-hold this genre in high esteem as one of the great achievements of modern Greek and late Ottoman popular culture, respectively. The author explores the ways rebetiko is perceived and performed in Istanbul and Athens in an era of Greek-marginality. This marginality, however, is redefined in relation to the present thus accounting, it is argued, for the emotional impact rebetiko continues to have on listeners in both countries.
\end{abstract}

